\title{
City Walk or Booklore?
}

\section{Eighteenth-Century Inscription Hunters in Action}

\author{
Bram Vannieuwenhuyze \\ University of Amsterdam, The Netherlands \\ b.j.vannieuwenhuyze@uva.nl
}

\author{
Martine De Reu \\ Ghent University, Belgium \\ martine.dereu@ugent.be
}

\begin{abstract}
This article offers a critical inquiry of the compilation of inscriptions and their transmission through books and manuscripts. It focuses on a bundle of hand-written slips which record about fifty-two inscriptions from early modern Brussels and which offers a glimpse on the preparatory work for publishing a town description or history. Its title suggests that the authors have used the peripatetic method, an approach in which an author, in the course of a stroll around a place, lists and describes any interesting buildings and sites he encounters. The method seems very appropriate when it comes to collect the texts of public inscriptions in a city or town, since it is generally thought that such texts on buildings could be read by every passer-by. Yet, nonetheless the authors of the Brussels' compilation certainly recorded texts while walking around in town, they apparently copied texts from existing books as well.
\end{abstract}

\section{Keywords}

inscriptions - urban space - antiquarianism - chorography - travelogues - Brussels eighteenth century 


\section{Introduction $^{1}$}

Inscription dans l'eglise de jesuittes placée au milieu du sanctuaire au dessus du maitre autel pres la voute.

These French words, written on a small piece of paper by an anonymous scholar, introduce the text of a Latin inscription that could be seen in the middle of the choir of the former Brussels Jesuit Church, somewhere above the main altar near the vault:

D.O.M.

Serenissimis Archiducibus

Albertus et Isabella. ${ }^{2}$

The inscription is a dedication 'To the Highest and Greatest God, the Most Serene Archdukes Albert and Isabella'. It seems reasonable to assume that it accompanied some pious donation by Archdukes Albert and Isabella, rulers of the Habsburg Low Countries on behalf of the Spanish king between 1598 and 1621, and fanatical promotors of the Counter-Reformation through their endowments to innumerable catholic institutions. Unfortunately, the inscription disappeared when the Jesuit Church was demolished in the early nineteenth century. ${ }^{3}$ We do not know exactly when it was created, by whom, for what reason, or on what occasion. Other questions also remain unanswered: what were the inscription's exact location and appearance? ${ }^{4}$ Did the

1 This article builds on and refines the analysis and hypotheses published earlier in M. De Reu and B. Vannieuwenhuyze, 'Stadswandeling of boekenwijsheid? Achttiende-eeuwse Brusselse opschriftenjagers aan het werk', in: T. Colleman et al., Woorden om te bewaren. Huldealbum voor Jacques Van Keymeulen (Ghent 2018), pp. 767-85. Bram Vannieuwenhuyze (University of Amsterdam) transcribed the texts from the Brussels compilation and studied their historical contexts, while Martine De Reu (Ghent University) translated the Latin fragments and checked whether the texts had been published before. We are most grateful to Gerre van der Kleij (GrondTaal), Jeannine De Landtsheer, and Elisabeth Vercammen for their assistance with the translations of the article and the inscriptions annotated in Appendix 1. Finally, we would like to thank both anonymous reviewers for their useful comments and suggestions.

2 Appendix 1, No. 19. The abbreviation D.o.m. stands for Deo Optimo Maximoque.

3 The Brussels Jesuit Church was built between 1606 and 1627 and destroyed in 1812; see J. Snaet, 'De jezuïetenkerk van Brussel en de XVIIde-eeuwse religieuze architectuur in de Zuidelijke Nederlanden', in: A. Deneef and X. Rousseaux, Quatre siècles de présence jésuite à Bruxelles. Vier eeuwen jezuïeten te Brussel (Brussels/Leuven 2012), pp. 152-70.

4 Curiously, the text is not visible on an interior view of the church by Anton Günther Ghering $(† 1668)$ (Munich, Alte Pinacothek, Bayerische Staatgemäldesammlungen, Inv. No. 6639). 
dedication apply to the altar or to the whole building? Was it easily legible to church visitors, and did they understand its message?

A thorough exploration of the Jesuit documents in the Brussels State Archives may provide direct or indirect clues to the answers and place the creation and reception of the inscription in a broader context. ${ }^{5}$ This in turn may shed some light on various aspects of the history and building of the church, on Jesuit patronage networks and their connection with the court, on the intentions and effects of religious and political propaganda, and on the degree of literacy of the Brussels population. Stated in more general terms: public inscriptions are a valuable source of information for scholars. To students of old literature and urban historians they are tools for conveying political and moralising messages to the contemporary public; toponymists compile inventories in order to study the origins and distribution of house names, while building historians and archaeologists use foundation inscriptions and chronograms to date building and restoration campaigns. In addition, inscriptions and public texts are a 'fitting subject for an investigation of a society's understanding of its own past', but they also reveal 'how modern societies have sought to associate themselves with, or even appropriate, the classical past of another'6

Epigraphy, the scientific study and interpretation of inscriptions, is a wellestablished and important subdiscipline of ancient history and archaeology, as illustrated by the monumental and ongoing publication project Corpus Inscriptionum Latinarum, which to date has resulted in seventeen volumes recording approximately 180,000 ancient Latin inscriptions, and by the frequent publication of epigraphic handbooks. ${ }^{7}$ Unfortunately, and somewhat surprisingly, when it comes to the study and interpretation of inscriptions from more recent periods few medieval and early modern historians build on the expertise, methods, and concepts developed by ancient historians and archaeologists. ${ }^{8}$ Many are content to collect only factual information, and to approach old inscriptions exclusively from the perspective of their own disciplines. In

5 See the inventory by H. Callewier, Inventaris van het archief van de Nederduitse provincie der jezuïeten (Provincia Belgica, vervolgens Provincia Flandro-Belgica) en van het archief van het professenhuis te Antwerpen, (1388) 1564-1773 (Brussels 2006), Nos. 2149-2218.

6 A. Cooley, 'The Life-Cycle of Inscriptions', in: A. Cooley, The Afterlife of Inscriptions. Reusing, Rediscovering, Reinventing \& Revitalizing Ancient Inscriptions (London 2000), p. 1.

7 See for instance J. Bodel, Epigraphic Evidence. Ancient History From Inscriptions (London 2012); Epigraphy and the Historical Sciences, ed. J. Davies and J. Wilkes (Oxford 2012), or The Oxford Handbook of Roman Epigraphy, ed. C. Bruun and J. Edmondson (Oxford 2015); for the Corpus Inscriptionum Latinarum, started in 1853 and continued and constantly updated by the Berlin-Brandenburgische Akademie der Wissenschaften; see https://cil.bbaw.de/.

8 There are of course exceptions; see for instance R. Favreau, Epigraphie médiévale (Turnhout 1997). 
general, data are used with (over-)confidence despite the importance of certainty with regard to the 'genuineness of the inscriptions'.

In a recent article, Glenys Davies emphasized that inscriptions are 'different from other more sculptural elements in that they can have an existence divorced from the object they are carved upon: they can be (and are) recorded and studied as texts written or printed on the page. ${ }^{10}$ According to Marco Buonocore, such 'handwritten treasures deserve to be part of the history of the epigraphic tradition', but unfortunately they are only 'slowly being rescued from undeserved oblivion by the efforts of modern scholars'.1 The only remedy against this 'divorce' is a combination of 'autopsy'-i.e. personal visual inspection —of the inscriptions' material remains and spatial context, with a study of editions and depictions of them in manuscripts, prints, drawings and paintings, by applying methods borrowed from linguistics, philology, history, bibliology, art, and building history, landscape studies, discourse analysis, and heraldry. We argue that book historians can also contribute expertise, especially with regard to understanding the compilation of inscriptions by earlier scholars and antiquarians and their transmission in written form. ${ }^{12}$ Copying an inscription extends its 'life-cycle. ${ }^{13}$ Scholars are understandably pleased with such copies, especially in cases where the original monuments have disappeared. However, these secondary sources often pose a number of additional interpretational problems, especially because past editors and antiquarians rarely explained how they compiled and subsequently presented their material in their publications.

In this article, we subject a bundle of hand-written slips of paper recording about fifty-two inscriptions from the exterior and interior of buildings in early modern Brussels, including the above mentioned dedicatory inscription from the former Jesuit Church, to a critical inquiry into their transmission in written form. ${ }^{14}$ The title on the first sheet of the bundle states that the compiled inscriptions were 'read on the façades of Brussels churches, monasteries, guesthouses and dwellings', which suggests that the so-called peripatetic method was used (Fig. 1). In this approach, the author in the course of a stroll

9 G. Davies, 'Inscriptions as Texts and Objects. Approaches to Epigraphic Publication in the Nineteenth Century', in: Journal of the History of Collections, 26 (2014), p. 373.

10 Davies, art. cit. (n. 9), p. 373.

11 M. Buonocore, 'Epigraphic Research from its Inception. The Contribution of Manuscripts', in: Bruun and Edmondson, op. cit. (n. 7), p. 36 .

12 Another topic would be the different links between epigraphy, typography and book design through time, as explored in A. Petrucci, Public Lettering. Script, Power, and Culture (Chicago/London 1993).

13 Cooley, art. cit. (n. 6), p. 3.

14 Brussels, Archives of the City of Brussels, Archives anciennes, liasse 825/3. 
around a certain place lists and describes any interesting buildings and sites encountered. ${ }^{15}$ The word 'peripatetic' derives from the ancient Greek word $\pi \varepsilon p i \pi \check{\alpha} \tau \circ \varsigma$, 'walking space, walk'. More specifically, it refers to Aristotle's custom of walking about during his morning and evening lectures in philosophy, and also to the building where these lectures took place. The empirical tenet Nihil est in intellectu quod non prius fuerit in sensu ("There is nothing in the intellect that has not first been in the senses') can be understood as a peripatetic axiom; Thomas Aquinas and John Lock, for instance, both believed that concepts and knowledge can only be acquired through sensory perception. ${ }^{16}$

The peripatetic method was shared by many seventeenth-, eighteenth- and nineteenth-century historians and antiquarians, who believed that sensory stimulation during a walk was the best way to familiarize oneself with a place. ${ }^{17}$ In addition, they tried to convey this attitude and feeling to their readers by metaphorically_and sometimes explicitly_presenting their text as a walk through the region, town, or place under scrutiny. The most famous example in the Netherlands is Jan Craandijk's series Wandelingen door Nederland met pen en potlood ('Walks through the Netherlands with pen and pencil'), published between 1875 and 1888 . However, the method was also applied to travelogues and topographies published from the sixteenth century onwards. ${ }^{18}$ Today, urban historians mostly start from other premises and may dismiss their predecessors' tours as trivial, but they still eagerly avail themselves of the many gold nuggets gathered during these perambulations.

The peripatetic method seems very appropriate when recording public inscriptions in a city or town. Indeed, it is widely assumed that such text fragments on the exterior or interior of buildings could be read by every passer-by. ${ }^{19}$ The authors of the Brussels compilation probably walked through the city,

15 B. Vannieuwenhuyze, 'The Study and Classification of Medieval Urban Toponymy. The Case of late Medieval Brussels (13th-16th centuries)', in: Onoma, 42 (2007), pp. 202-3.

16 W.E. Mann, 'Nihil est in Intellectu Quod Non Prius Fuerit in Sensu', in: R. Audi, Cambridge Dictionary of Philosophy (2nd edn.; Cambridge 1999), p. 617; see also P.F. Cranefield, 'On the Origin of the Phrase Nihil est in Intellectu Quod nON PriUs fuerit in SENSU', in: Journal of the History of Medicine and Allied Sciences, 25 (1970), pp. 77-80.

17 C.A.M. Clarke, 'Introduction. Medieval Chester. Views from the Walls', in: C.A.M. Clarke, Mapping the Medieval City. Space, Place and Identity in Chester c. 1200-1600 (Cardiff 2011), p. 4. Clarke refers, among others, to John Broster's A Walk Round the Walls and City of Chester (1821), in which the traveller is conducted regularly 'from scite to scite'.

18 See E. Verbaan, De woonplaats van de faam. Grondslagen van de stadsbeschrijving in de zeventiende-eeuwse Republiek (Hilversum 2011), pp. 158-61, who discusses the example of Johannes Thysius' Description de Paris from 1646.

19 See R. Favreau, Epigraphie médiévale (Turnhout 1997), p. 31; and A. Castillo Gómez, 'Entre public et privé. Stratégies de l'écrit dans l'Espagne du Siècle d'Or', in: Annales. Histoire, Sciences Sociales, 56 (2001), p. 8 og. 


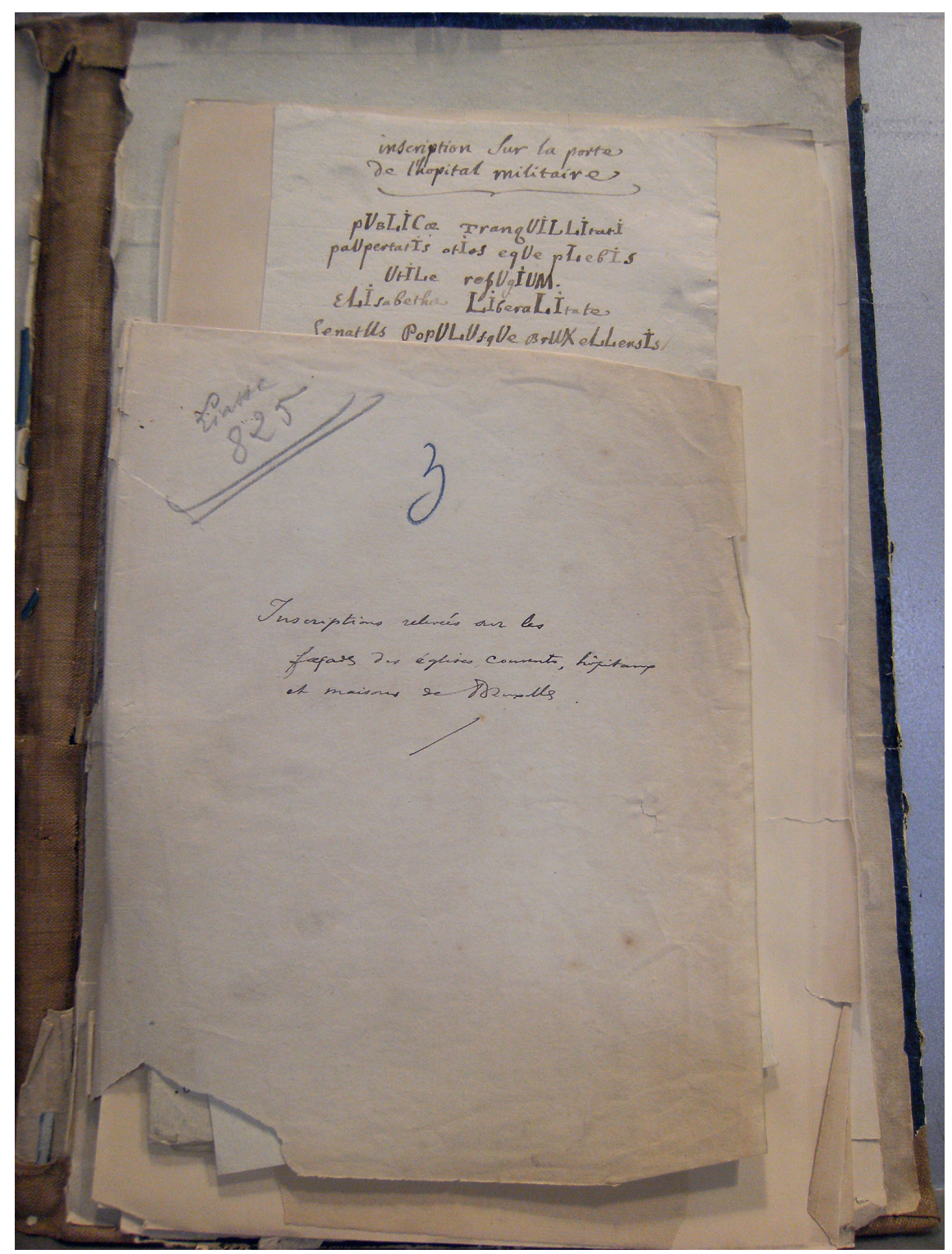

FIGURE 1 First sheet of the Brussels' bundle with inscriptions, entitled Inscriptions relevées sur les façades des églises, couvents, hôpitaux et maisons de Bruxelles BRUSSELS, ARCHIVES OF THE CITY OF BRUSSELS, ARCHIVES ANCIENNES, LIASSE $825 / 3$ 
looked at façades, perhaps even entered buildings, read the inscriptions, and took notes. However, establishing a route on the basis of the inscriptions as recorded in the bundle is very complicated if not downright impossible. Since the paper slips in the compilation are not bound together their original sequence may well have changed, making it impossible to reconstruct the original itinerary on the basis of their current order. Moreover, Brussels itself has changed enormously since the late eighteenth century. ${ }^{20}$ Of the fifty-two inscriptions in the compilation only a handful are still extant, making an autopsy of the material remains virtually impossible. ${ }^{21}$ Consequently, extensive efforts were made to trace additional information on the recorded inscriptions. Appendix 1 presents a summary of the resulting information: an identification of the original buildings which contained the inscriptions, any date mentioned in them or in the introductory titles, an edition of all texts, an English translation of the Latin and Dutch phrases, and a summary of possible editions in printed books published between the sixteenth and nineteenth centuries. ${ }^{22}$ Our research allowed us to reflect on the inscription hunters' heuristic methods and on the goal and intention of their work. Hopefully, our processual approach of this particular source linking its possible use to its production, will inspire scholars who are working with similar compilations or themes.

\section{A Bundle of Inconsistent Preparatory Notes}

Very little information exists on the origin of the Brussels compilation, since it is neither dated nor signed. It lacks a colophon, page numbers, or an explanatory introduction. The notes are jotted down in a number of different hands and they do not reproduce the script and layout of the monumental originals (Fig. 2). The authors, all of whom wrote in French, do not introduce themselves and thus remain anonymous. They frequently added introductory titles to locate and contextualise the inscriptions, or briefly commented on them. Occasionally, as in the case of the dedicatory text in the Jesuit Church cited in the introduction, the authors mention the inscription's original position,

$20 \quad$ For an overview, see Brussel, breken, bouwen. Architectuur en stadsverfraaiing 1780-1914 (Brussels 1979); and Th. Demey, Bruxelles. Chronique d'une capitale en chantier (Brussels 1990-1992).

21 The inscriptions on the so-called Minerva Fountain on the Zavel Square (Appendix 1, No. 37) and on some of the façades which line the Grand'Place (Appendix 1, Nos. 22, 42, 43, 44 and 45).

22 Neither the inscriptions nor the slips of paper are sequentially numbered; we have therefore assigned a serial number to each individual item in Appendix 1. 
presumably in an attempt to lend validity to their notes. ${ }^{23}$ The introductory title to the inscription on the Fishmongers' Guildhall, for instance, states that the text was located on the hall's east façade. An additional note provides details regarding the building's renovation in 1770 on the occasion of the fourhundredth anniversary of the Sacrament of Miracle, a renovation which in fact obliterated the inscription. ${ }^{24}$

According to Charles Pergameni, the bundle was compiled at the end of the eighteenth century. ${ }^{25}$ The character of the various samples of handwriting points in that direction, as do several dates and chronograms in the inscriptions themselves; the most recent dates mentioned are 1780 and $1787 .^{26}$ In one of the introductory titles an author states that he copied the text 'in the house of Mr. Rutty, banker mason, on 4 July 178o'.27 The subtitle, which introduces the placard against heretical sentiments that was attached to the walls of St. Gudula Church on 22 March 1783, 'lorsque Joseph 2 etoit reignant', must have been written after the reign of the Habsburg Emperor Joseph II (1765-179o), possibly at the time when Brussels was under French administration (1794-1815). ${ }^{28}$ Clearly, the authors were active during a longer period. It is known that several individuals took to the pen during the long transitional period which encompassed the reforms of Joseph II, the Revolution, and the French occupation, which was marked by chaos. ${ }^{29}$

In view of the city's size and significance, comprising $45^{\circ}$ ha and 75,000 inhabitants, ${ }^{30}$ it is striking that only fifty-two inscriptions were recorded. Moreover, of these fifty-two, St. Gudula Church (four inscriptions), and the Bread Hall (six inscriptions) together contributed one-fifth of the entire collection. ${ }^{31}$ Three inscriptions were recorded at the Jesuit Church and at the

23 Davies, art. cit. (n. 9), p. 376.

24 Appendix 1, No. 6; see also A. Wauters, 'L'ancienne maison des poissonniers, à Bruxelles', in: Bulletin des Commissions royales d'Art et d'Archéologie, 14 (1875), pp. 312-13.

25 Ch. Pergameni, Les archives historiques de la Ville de Bruxelles (Brussels 1943), p. 219.

26 Appendix 1, Nos. 40 and 23.

27 Appendix 1, No. 24-Mr. Rutty's profession probably enabled him to collect marble stones and plates from demolished buildings and prepare them for reuse elsewhere.

28 Appendix 1, No. 36.

29 J. Pollmann, 'Archiving the Present and Chronicling for the Future in Early Modern Europe', in: Past and Present, 230 (2016), Supplement 11, p. 242; evolutions in historiography during the French occupation are meticulously analysed in B. Deseure, Onhoudbaar verleden. Geschiedenis als politiek instrument tijdens de Franse periode in België (Leuven 2014).

30 Population figures for early modern Brussels are provided and discussed in F. Daelemans, 'De bevolking tijdens het ancien régime', in: Het Gewest Brussel. Van de oude dorpen tot de stad van nu, ed. A. Smolar-Meynart and J. Stengers (Brussels 1989), pp. 130-7.

31 Appendix 1, Nos. 2, 3, 4 and 36 (St. Gudula Church), and 46, 47, 48, 49, 50 and 51 (Bread Hall). 


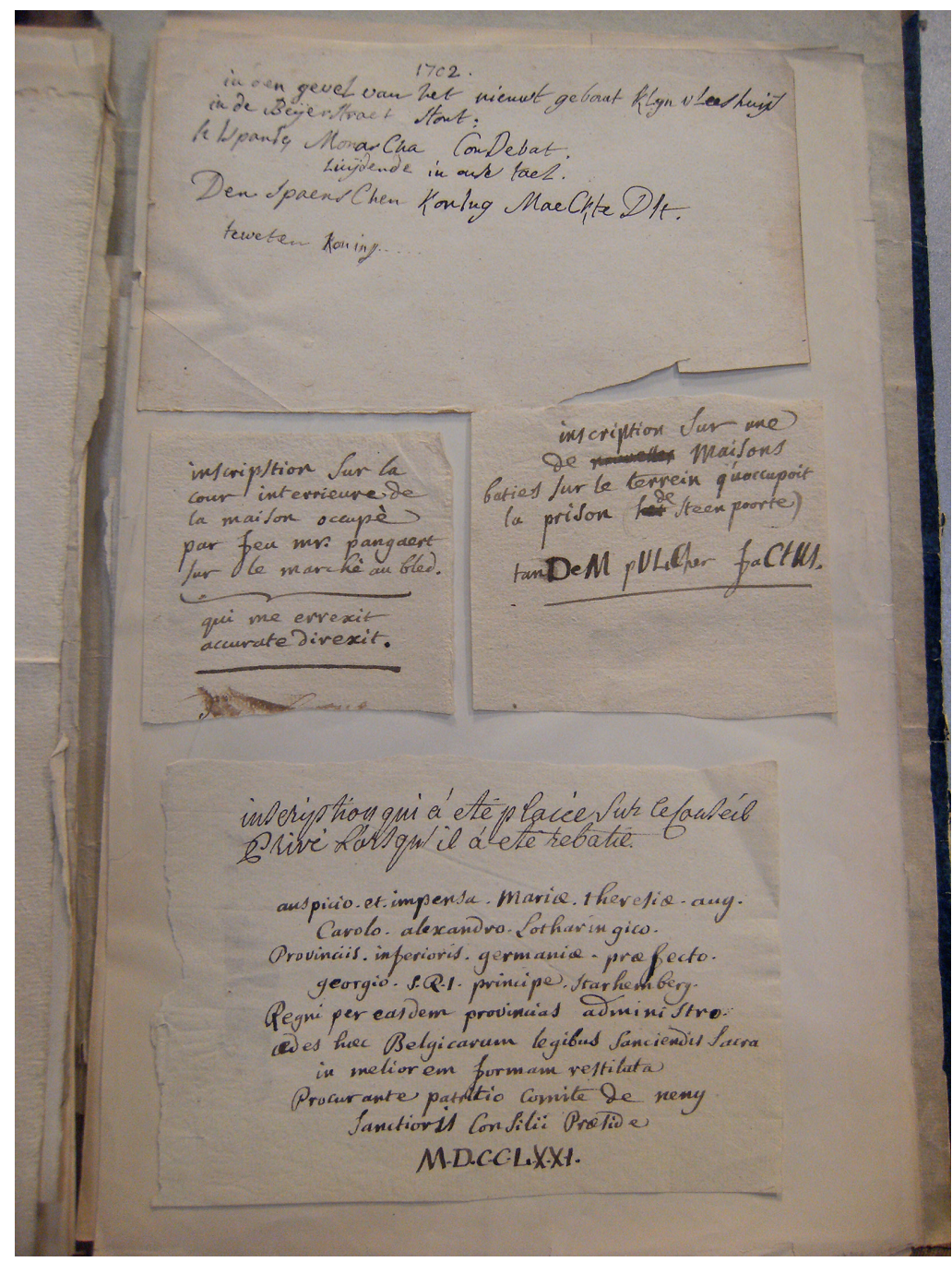

FIGURE 2 The notes of the Brussels' compilation have been jotted down in a number of different hands; French introductory titles contextualise the inscriptions or briefly comment on them BRUSSELS, ARCHIVES OF THE CITY OF BRUSSELS, ARCHIVES ANCIENNES, LIASSE 825/3 
Military Hospital, while the Union Hotel on the Grand'Place provided two. ${ }^{32}$ The inscription on the Small Butchers' Guildhall is recorded twice. ${ }^{33}$ The remaining thirty-one buildings each contributed one inscription. The total number of buildings is thirty-eight: a small number for such a large city. Fifteen of the recorded texts originate in the eighteenth century, eleven in the seventeenth century, and two date from the sixteenth century. Only one inscription seems to date back to the late medieval period. ${ }^{34}$ This is surprising, for some historians believe that cities and towns in the Low Countries were being filled with texts at this time. ${ }^{35}$

Of course, the anonymous authors did not compile all the public texts that at the time existed in the city of Brussels. Moreover, a note on the fourth slip of paper suggests that the 'hunt for inscriptions' was not completed; the note includes a 'to do' list, a reminder to record certain inscriptions at a later time. Eight buildings are mentioned by name, but the note also refers in more general terms to churches and to houses on the Grand'Place. With the exception of the Royal Library, these buildings are indeed absent from the collection. ${ }^{36}$ It is not clear why the authors abandoned their inscription hunt, but this abandonment was not exceptional. According to Tom Verschaffel, much historical research in the eighteenth century remained unfinished and unpublished. Although high production costs also played a part, the main reason was that other work took priority and that historiography was never a main source of income. ${ }^{37}$ We carefully checked whether the inscriptions recorded in the compilation were included as a group in one of the various sixteenth-, seventeenth- or eighteenth-century Brussels town histories, town descriptions, or travelogues. ${ }^{38}$ The answer is negative. It is thus very likely that the work

32 Appendix 1, Nos. 14, 15 and 19 (Jesuit Church), 16, 17 and 18 (Military Hospital) and 44 and 45 (Union Hotel).

33 Appendix 1, Nos. 8 and 25.

34 Appendix 1, No. 4. Although several inscriptions omit to mention a year, making it difficult to date them.

35 See for instance J. van Leeuwen, 'Over slapscheten en levereters. Pamfletten en strooibriefjes in de laatmiddeleeuwse Vlaamse stad', in: Madoc, 18 (2004), pp. 77-8; H. Pleij, 'De geletterde stad en de literatuur van de late middeleeuwen', in: Spiegel der Letteren; 48 (2006); p. 121; H. Pleij, Het gevleugelde woord. Geschiedenis van de Nederlandse literatuur 1400-1560 (Amsterdam 2007), p. 757.

36 Appendix 1, No. 24.

37 T. Verschaffel, De hoed en de hond. Geschiedschrijving in de Zuidelijke Nederlanden 1715-1794 (Hilversum 1998), p. 109.

38 See Appendix 2; this list is in part based on J.T. Bodel Nijenhuis, 'Opgave van beschrijvingen der gewesten, steden en plaatsen in het koningrijk der Nederlanden', in: De Vriend des Vaderlands, 4 (1830), pp. 24-5. 
of the Brussels inscription hunters remained unpublished and that only these preparatory notes survive. ${ }^{39}$

We may however assume that the authors intended to publish the recorded inscriptions, either as part of a town history or description, or as a specific edition. An ancient and lively tradition existed in Europe of compiling and publishing series of public inscriptions. Codex 326 in the library of the Benedictine monastery of Einsiedeln written in the third quarter of the ninth century, is the oldest known and most famous collection of Roman inscriptions. ${ }^{40}$ According to John Sparrow, "the sixteenth century saw the emergence of a new type-or, one may say, two new types - of books: the collection of classical, and the collection of contemporary inscriptions. ${ }^{41}$ Although Desiderio Spreti's De amplitudine, de vastatione et de instauratione Urbis Ravennae, published in Venice in 1489 , is generally regarded as the first printed work in the field of ancient epigraphy, scholars point at the Epigrammata Antiquae Urbis, edited and printed in Rome in 1521 by Giacomo Mazzocchi, as the 'first really focused collection' or 'first considerable printed collection' devoted to Roman inscriptions. ${ }^{42}$

Printed books containing collections of contemporary-i.e. not ancientinscriptions were published from the mid-sixteenth century onwards. Initially the phenomenon was rare but from the seventeenth century onwards it gained in popularity in the countries north of the Alps. ${ }^{43}$ As for Brussels, a city without Roman antecedents, the only compilations of this kind are the printed Recueil général des inscriptions faites \& exposées aux jours des rejouissances publiques depuis le couronnement de l'empereur Charles VI de glorieuse mémoire jusques au couronnement de l'empereur François Premier, published by André de Vos, probably in the mid-seventeenth century, and the Dissertation critique et analytique sur les chronogrammes, edited by the widow Foppens in 1751. However, the publication of printed books did not mean the end of the manuscript tradition: in the seventeenth and eighteenth centuries, many 'handwritten collections of inscriptions, comprising documents from individual cities, or notes on

39 How the compilation ended up in the Brussels' city archives is unknown. In his inventory, Charles Pergameni does not provide any details as to its provenance, see Pergameni, op. cit. (n. 25), p. 219. There may be a connection with the Sophie and/or Locquenghien families, since the compilation is part of a larger file entitled Papiers de famille ('Family documents'), which also contains genealogical notes on these two Brussels' families by the former city archivist Alphonse Wauters in 1845 .

40 Buonocore, art. cit. (n. 11), p. 21; for an edition and facsimile of the Einsiedln Codex, see Die Einsiedler Inschriftensammlung und der Pilgerführer durch Rom (Codex Einsidlensis 326), ed. G. Walser (Stuttgart 1987).

41 J. Sparrow, Visible Words. A Study of Inscriptions in and as Books and Works of Art (Cambridge 1969), p. 25 .

42 Buonocore, art. cit. (n. 11), pp. 33-34; and Sparrow, op. cit. (n. 41), p. 25.

43 Sparrow, op. cit. (n. 41), pp. 26-7. 
local history and archaeology, in which inscriptions feature, continued to be produced'. ${ }^{44}$ The Brussels compilation certainly belongs to this group of documents, as does a series of manuscript épitaphiers containing dozens of funeral inscriptions in the city's main churches. ${ }^{45}$

The Brussels compilation, however, is an unusual case: the summary in Appendix 1 reveals that its format and content are quite inconsistent, making it difficult to speculate about the motives of the authors. ${ }^{46}$ Different types of buildings and inscriptions alternate, and they seem to have encompassed various neighbourhoods of eighteenth-century Brussels. ${ }^{47}$ As was mentioned earlier, reconstructing the authors' virtual walk on the basis of the inscriptions is impossible, particularly as it appears to have been a long-term project by a group of people. Nevertheless, by selecting or omitting particular texts, buildings, or neighbourhoods the inscription hunters envisaged or propagated an imaginary urban space. They seem to have been particularly interested in official inscriptions - i.e. public texts commissioned, granted, or at least tolerated by the public authorities - and most of them were to be found in the oldest and most prosperous parts of Brussels: notably in the neighbourhoods of the Grand'Place, the Court, St. Gudula Church and St. John's Hospital (Fig. 3). The poorer quarters down town or at the outskirts of the city were almost entirely ignored.

Rather surprisingly, the authors failed to record a single inscription from the recent neo-classical quarters of Sint-Michielsplein, Koningsplein, Groot Godshuis or de Munt. The white façades of these new architectural ensembles marked the start of the so-called blanchiment de la ville ('the whitening of the city'), which undoubtedly caused the disappearance of many inscriptions. ${ }^{48}$ It is possible that the inscription hunters reacted against this 'epigraphic downfall' and the precarious situation of all those public inscriptions that bore witness to Brussels' glorious past. ${ }^{49} \mathrm{~A}$ similar motivation lay behind Fra Giocondo

\footnotetext{
44 Buonocore, art. cit. (n. 11), p. 36.

45 Brussels, Archives of the City of Brussels, Archives anciennes, Nos. XxV, XxVI, 2970 3407, 3408, 3409, 3410 and 3411; see Pergameni, op. cit. (n. 25), pp. 217-19.

46 According to Sparrow, 'sometimes inscriptions were collected for their intrinsic beauty, sometimes for their association with a particular town or district; while sometimes [...] a publisher would assemble the productions of a particular composer. [...] They ministered to regional feeling, to civic sense, to antiquarian curiosity, to family pride., see Sparrow, op. cit. (n. 41), pp. 26-7).

The types of inscriptions and buildings and their location and distribution in the city are discussed in B. Vannieuwenhuyze, 'De "vertekstlozing" van de stad? De vergankelijkheid van publieke opschriften in achttiende-eeuws Brussel', in: Tijdschrift voor Geschiedenis, 131 (2018), pp. 107-11.

48 C. Loir, Bruxelles néoclassique. Mutation d'un espace urbain 1775-1840 (Brussels 20o9), p. 50.

49 For a more comprehensive discussion, see Vannieuwenhuyze, art. cit. (n. 47), pp. 114-17.
} 


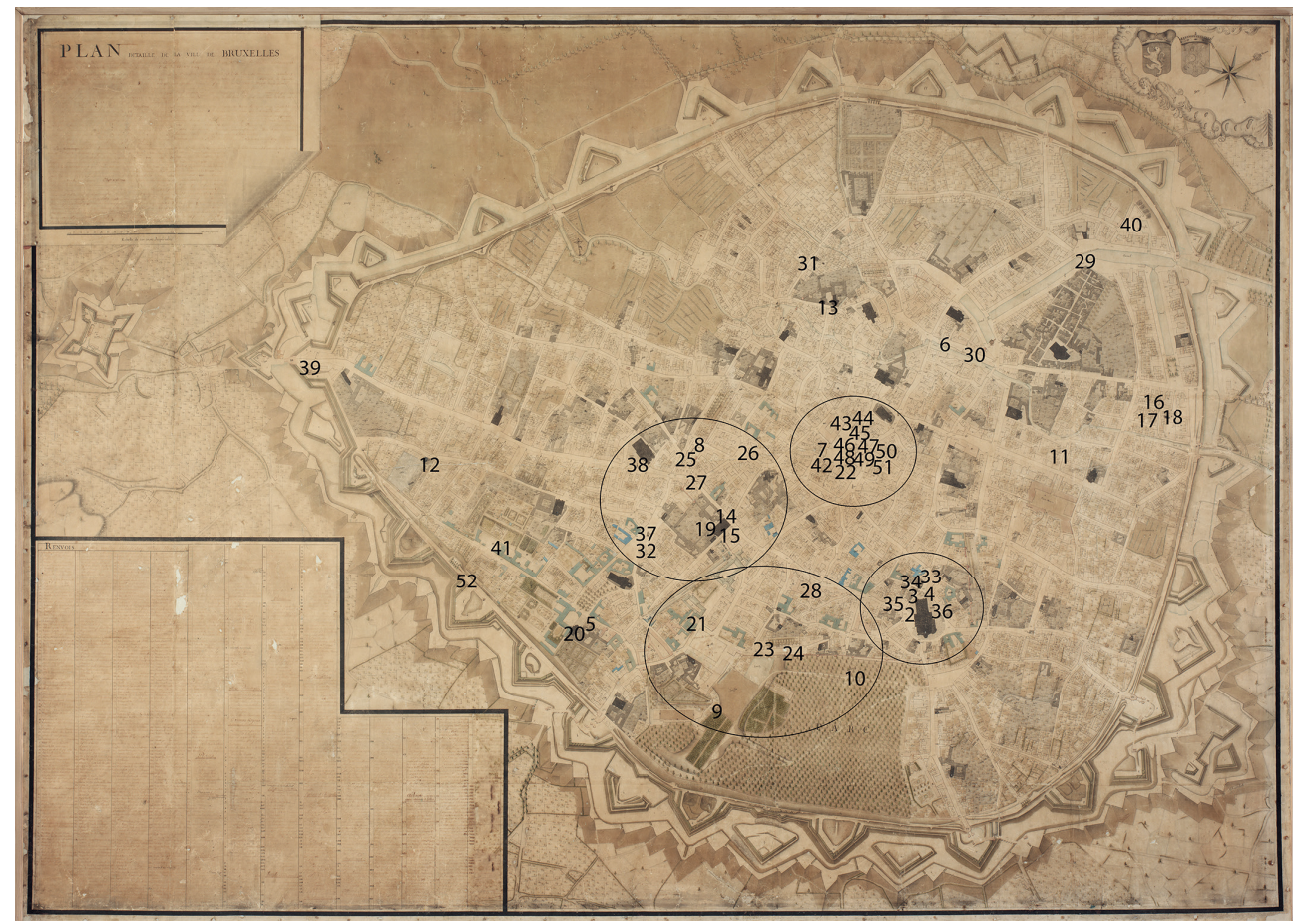

FIGURE 3 Distribution of the buildings and sites where the inscriptions recorded in the Brussels' compilation could be found, mapped on the Plan détaillé de la Ville de Bruxelles by Lefebvre d'Archambault from 1774 BRUSSELS, ARCHIVES OF THE CITY OF BRUSSELS, PLAN DE BRUXELLES GRAND FORMAT, NR. 2

of Verona's 1489 publication of his Collectio inscriptionum Latinarum et Graecarum: 'there are many ruins in that famous city', he lamented, 'from which yet more ruins are created day by day'.50 The derelict state of the ancient buildings and their ongoing destruction certainly threatened the town's many ancient inscriptions. In this respect both the Brussels compilation and Fra Giocondo's publication do not really belong to the popular genre of the laudatory city description ${ }^{51}$ but rather to that of the lamentatio, such as Zeger van Male's jeremiad on the decline and depletion of the city of Bruges, written in the second half of the sixteenth century.52

50 Ruinae tamen ipsius urbis multae sunt, ex quibus item novae ruinae in dies fiunt; see Buonocore, art. cit. (n. 11), p. 3 .

$5^{1} \quad$ For an in-depth discussion of this genre, see Verbaan, op. cit. (n. 18).

$5^{2}$ Brugge na de opstand tegen Spanje. De lamentatie van Zeghere van Male, ed. A. Dewitte and A. Viaene (Bruges 1977). 


\section{Inscription Hunters in Action}

In his contribution to The Oxford Handbook of Roman Epigraphy Marco Buonocore emphasized the necessity not only of the identification of the author of a manuscript but also of an assessment of that author's overall reliability by evaluating his modus operandi. A 'fully rounded epigrapher', Buonocore argued, 'must also be a good philologist and, when editing an inscription, especially if the original text no longer survives for inspection, must consider as closely as possible the manuscript tradition (and even early printed works), attempting to explain the differing readings and renderings of the text that these sources provide'. ${ }^{3}$ Although the format and scope of this article prevent us from presenting a complete philological edition of the inscriptions in the Brussels compilation, the question as to how the anonymous authors compiled their information must nonetheless be addressed.

The title on the first sheet of the bundle suggests the peripatetic method; it explicitly states that the inscriptions were taken from the façades of various types of buildings (Inscriptions relevées sur les façades des églises, couvents, hôpitaux et maisons de Bruxelles). The introductory title explaining the position of the dedicatory inscription in the Jesuit Church reinforces this suspicion, as it suggests that it had been seen and read in situ. ${ }^{54}$ We may reasonably assume that most of the inscriptions on the façades of private houses were also recorded on the spot. ${ }^{5}$ In the case of inscriptions such as Qui me errexit accurate direxit, visible from the inner courtyard of the house of the late Mr. Pangaert, the authors must either have had access to private or semi-public spaces or have received the information from the owners or residents. ${ }^{56}$ The only alternative method to compile this kind of data would be by consulting administrative documents such as census data or the so-called penningkohieren. Although these fiscal documents contain hundreds of house names, there is no indication that the authors had access to them. ${ }^{57}$ If they had, we would expect the compilation to be more coherent and to contain more house names.

53 Buonocore, art. cit. (n. 11), p. 22.

54 Appendix 1, No. 19.

55 Appendix 1, Nos. 1, 21, 22, 23, 26, 27, 30, 31, 32, 33, 35, 41 and 42.

56 Appendix 1, No. 26.

57 The censuses of 1702 and 1767 have been published; see respectively De volkstelling van 1702 in Brussel en omgeving, ed. H. Swinnen (Leuven 2018); and A. Mehauden and M. Vanwelkenhuyzen, La Ville de Bruxelles. Ses habitants, leurs métiers et leurs adresses vers 1767 (Brussels 1998). The preserved Brussels' penningkohieren or cahiers des vingtièmes span the period 1699-1793 (Vorst, State Archives in Brussels, Archives des États de Brabant, Nos. 5672-6oo8). 
While we may assume that some texts were copied directly from the original inscriptions, there are strong indications that the authors did not limit themselves to field work alone. Some of the introductory titles are based on additional oral or written sources. One author for instance refers to the sale and melting of a cannon and provides a range of data that cannot have been collected in situ. ${ }^{58}$ The explanatory notes to the inscription on the Small Butchers' Guildhall, hIspanIae MonarCha ConDebat ('The King of Spain established this'), were left unfinished as the author did not know which Spanish king was meant. ${ }^{59}$ Such information had to be gleaned from historical books and manuscripts. The authors also included inscriptions that had already been removed, another indication that they did more than tracing and recording the texts en route. We already mentioned the inscriptions in the Royal Library, which were removed in 1772. Luckily, in this case the author was able to copy the text in 1780 in the house of a certain Mr. Rutty. ${ }^{60}$ On 22 March 1783 , another person copied the text of a subversive placard on St. Gudula Church which probably did not stay in place for very long. ${ }^{61}$

The compilation even includes a separate cahier containing inscriptions detruittes ou supprimées (Fig. 4), starting with three texts from St. Gudula Church' Sacrament Chapel, built in $1436-1438 .^{62}$ The first two texts refer to the story of the alleged desecration of the Host by several Brussels Jews in 1370, and invites travellers to halt and praise God. ${ }^{63}$ The third inscription states that in 1387 seven prominent Brussels families commissioned a stained glass window with an inscription for the chapel. ${ }^{64}$ The building was demolished in 1533 and replaced by the present Sacrament Chapel. In his Bruxelles Illustrée, Josse Ange Rombaut remarked that the first inscription had been 'destroyed by iconoclasts'; with regard to the second he merely reported that it had been removed. ${ }^{65}$ By the late eighteenth century the verses had therefore long since disappeared. However, the eighteenth-century inscription hunters were still able to trace the text in several early modern publications, e.g. Lodovico Guicciardini's

\footnotetext{
$5^{8} \quad$ Appendix 1, No. 9; see also the notes between Nos. 36 and 37.

59 Appendix 1, No. 25.

6o Appendix 1, No. 24.

61 Appendix 1, No. 36.

62 P. Lefèvre, De collegiale kerk van Sint-Michiel en Sinte-Goedele te Brussel. Geschiedenis. Architektuur. Meubileering. Schat (Antwerp 1942), p. 32.

63 Appendix 1, Nos. 2 and 3.

64 Appendix 1, No. 4-There are many reasons to doubt the authenticity of both the stained glass window and its inscription; see M. Martens, 'Un vitrail disparu aux armes de lignages bruxellois à la cathédrale Saint-Michel', in: Miscellanea Jozef Duverger (Ghent 1968), pp. 411-27; and De Reu and Vannieuwenhuyze, art. cit. (n. 1), pp. 772-4.

65 J.A. Rombaut, Bruxelles illustrée ou description chronologique et historique de cette ville, tant de son ancienneté, que de son état présent (Brussels 1777-1779), vol. I, p. 210 and pp. 211-12.
} 


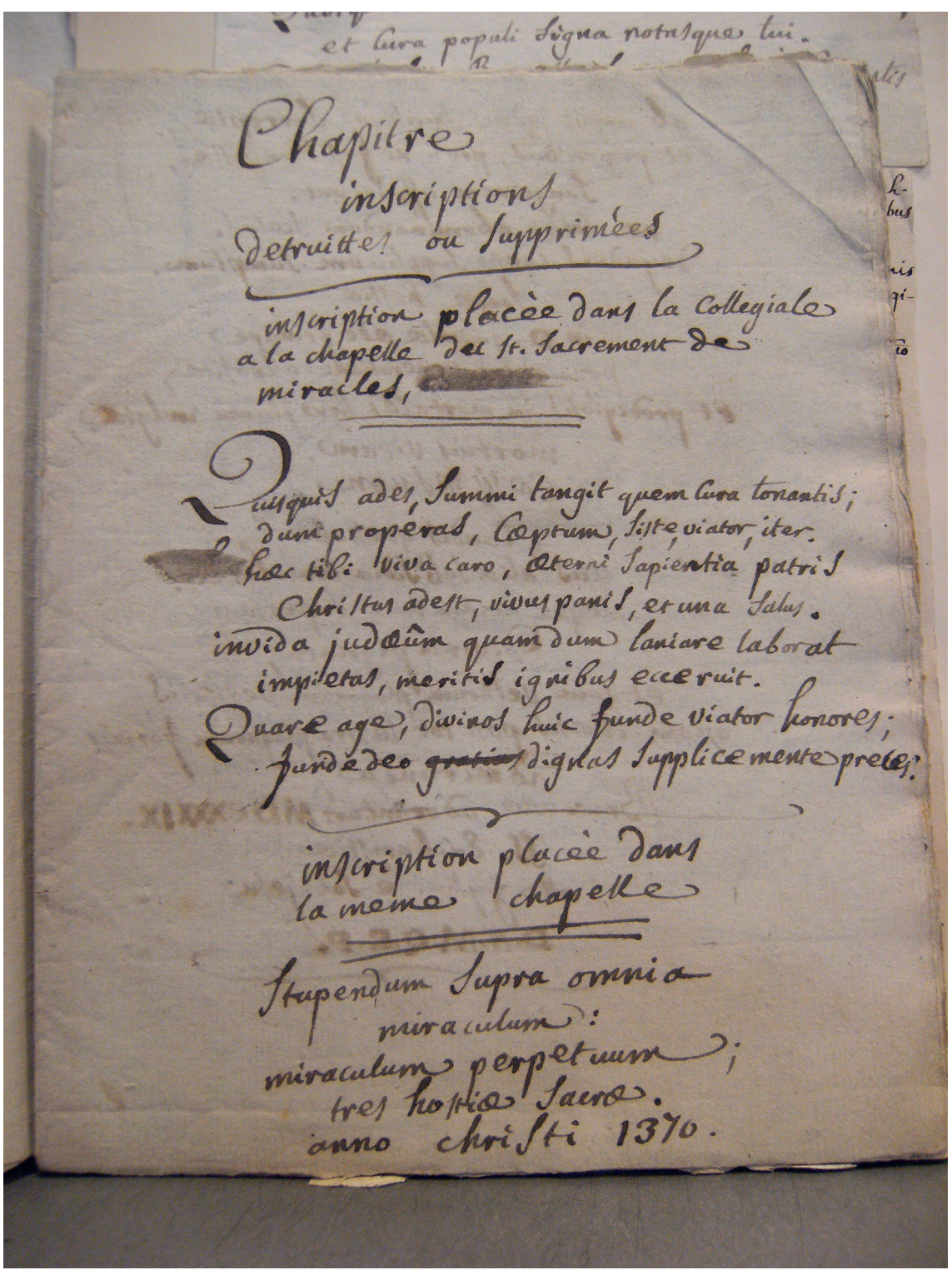

FIGURE 4 First page of the separate cahier with the Chapitre inscriptions detruittes ou supprimées

BRUSSELS, ARCHIVES OF THE CITY OF BRUSSELS, ARCHIVES ANCIENNES, LIASSE $825 / 3$ 
famous Descrittione di tutti i Paesi Bassi first published in 1567, or Rombaut's 1777-1779 Bruxelles Illustrée.

The next inscription detruitte ou supprimée brings us to a 'pyramid' on the former grounds of the town house of the Culemborg family, near the Brussels Koudenberg. ${ }^{66}$ In 1568 the Duke of Alba ordered a commemorative column to be raised as a retaliation against the so-called 'Compromise of Nobles' which occurred in the house. The column was short-lived: after the 1576 Pacification of Ghent, orders were issued for the destruction of 'the columns, trophies, inscriptions and other tokens, raised by the Duke of Alba, disgracefully and infamously'.67 Yet in the late sixteenth century the Latin inscription reappeared in several editions of Emanuel van Meteren's book on the start of the Eighty Years' War. ${ }^{68}$ Another inscription that was later removed is said to have derived from the Fishmongers' Guildhall in the lower town. ${ }^{69}$ The text links the guildhall's foundation to generous donations by the Spanish king, Philip IV. A note to the text explains that the inscription disappeared in the course of repairs carried out in 1770. According to Alphonse Wauters, the inscription was placed on the façade facing the river, inside a medallion between the second and third window of the first floor. ${ }^{70}$ It was therefore legible only from the river Zenne, and perhaps also from the adjacent Vismarkt Square. An old pen-andink drawing ascribed to Ferdinand-Joseph Derons shows the medallion as seen from that perspective, but the text is illegible. ${ }^{71}$ Since both the building and the inscription have vanished and the drawing lacks sufficient detail, the compilation is our only source of information. Did the eighteenth-century 'inscription hunters' personally see and record this inscription - which would mean they were already active in the 176 os — or did they obtain their information from another source?

The next text fragment was originally inscribed in the pedestal of an equestrian statue of governor Maximilien-Emmanuel de Bavaria, erected in 1697 on top of the rebuilt Brewers' Guildhall on Grand'Place. ${ }^{72}$ Whether passers-by were able to read the text from the street is doubtful. Even if they could, they

\footnotetext{
66 Appendix 1, No. 5 .

67 J. Gysius, Oorspronck ende Voortgang der Neder-landscher Beroerten (Delft 1626), p. 555.

68 E. Van Meteren, Historia, unnd [sic] Abcontrafeytungh, fürnemlich der Niderlendischer geschichten, und Kriegsz hendelen, mit höchstem fleisz beschrieben (Köln 1593), vol. III, p. 12.

69 Appendix 1, No. 6.

$70 \quad$ Wauters, art. cit. (n. 24), p. 313.

71 Brussels, Royal Museums of Fine Arts of Belgium, inv. nr. 1532; see also A. Deknop, Van't stadt en schoone buytens. Een kijk op Brussel en omgeving in de 18de eeuw. Tekeningen en schilderijen van F.J. Derons en A. Martin (Brussels 2007), pp. 40-1. 
may not have understood it, for the text is riddled with metaphors. ${ }^{73}$ The authors of the compilation may never have seen the inscription, for in $175^{2}$ the statue was replaced by another, this time of governor Charles Alexander of Lorraine. The anonymous author of the Chronyk van Brussel laconically wrote: 'after his death, the statue may be replaced again.' ${ }^{74}$ Indeed, in 1794 this second statue was also removed. The text of the earlier inscription however survived in a 1719 printed travelogue by Leonhard Christoph Sturm, and also in the Description de la Ville de Bruxelles, published by Georges Fricx in $1743{ }^{75}$

Next in the small cahier are the inscriptions on the Small Butchers' Guildhall, on a cannon near Koudenberg Palace, and on a fountain in Koudenberg Park commemorating the sojourn of Russian Tsar Peter the Great in Brussels in $1717-1718 .{ }^{76}$ The authors may not have seen these texts in situ, for by the late eighteenth century the guildhall had been transformed into a concert hall, the cannon had been melted down, and the fountain no longer stood in the park. However, the first two inscriptions could be found in seventeenth- or eighteenth-century publications. Where the eighteenth-century inscription hunters encountered the commemorative inscription for Peter the Great is unknown, but it does appear in nineteenth-century publications.

Clearly the small cahier containing the nine inscriptions detruittes ou supprimées is more than just a compilation of texts that were once publicly visible in Brussels. The authors could not have collected this information by walking around and looking at façades. They must have used other sources, especially printed sixteenth-, seventeenth- and eighteenth-century books. The last column in Appendix 1 lists the various sources to which the authors had access. Nearly all inscriptions detruittes ou supprimées had already been published, albeit separately, in chorographies such as Guicciardini's Descrittione di tutti i Paesi Bassi, travelogues such as Missons Nouveau Voyage d'Italie, historical accounts such as Van Meterens Historia, unnd [sic] Abcontrafeytungh, fürnemlich der Niderlendischer geschichten, and of course also in descriptions and

73 The first two sentences refer to the aid provided by the governor towards the rebuilding of the Grand'Place after the French bombardment of Brussels of 1695, which had reduced the square to a smoking ruin. The last sentence alludes to Maximilien-Emmanuel's participation in battles against the Turks at Vienna and Belgrade. See A.-G. Demanet, 'Note sur la statue de Maximilien-Emmanuel, électeur de Bavière, placée en 1697 sur la Maison des Brasseurs, à Bruxelles', in: Bulletin des Commissions royales d'art et d'archéologie (1879), pp. 46-7; É. Hennaut, 'La reconstruction après le bombardement', in: Les Maisons de la Grand-Place de Bruxelles, ed. V. Heymans (Brussels 2007), p. 67.

74 Demanet, art. cit. (n. 73), p. 47.

75 This may explain why the inscription hunters were either unaware of or ignored the fact that the first sentence contains a chronogram: DVX BaVarIae BrVXxeLLensIVM saLVs yields 1697 .

76 Appendix 1, Nos. 8, 9 and 10. 
histories of Brussels itself. The two exceptions are the inscription on the façade of the Fishmongers' Guildhall and the one on the Koudenberg Park fountain, but the fact that both texts were included in nineteenth-century publications indicates that one way or another they too were transmitted.

At least eleven supplementary inscriptions from the compilation could also be found in itineraries, travelogues, and town descriptions. ${ }^{77}$ The texts on the façade of the Small Butchers' Guildhall, on the house built on the site of the former Steenpoort Prison, or on the Zavel Square fountain, for instance, were all published in eighteenth-century town descriptions such as Description de la ville de Bruxelles (1743), Le guide fidele, contenant la description de la ville de Bruxelles tant ancienne que moderne (1761), and Description de la ville de Bruxelles (1782). The text of the inscription on the Rubempré town house even exactly repeats the punctuation used by the anonymous author of the 1743 Description de la ville de Bruxelles, who confessed that it was 'invented' by him (l'inscription suivante avec les ponctuations que $j$ 'y mets). ${ }^{78}$ Without any doubt, this piece of text has been copied from this book and not from the original building inscription. The inscriptions on some of the houses on the Grand'Place and on the Bread Hall appear in several publications. Most of them and some others as well later reappear in Alexandre Henne and Alphonse Wauters' 1845 Histoire de Bruxelles, which is generally considered to be the first scholarly monograph on the history of Brussels. ${ }^{79}$ Unfortunately, Henne and Wauters never mentioned their sources for this particular type of information. Since several buildings no longer existed in their time, they may have copied the texts from older books and manuscripts.

Did their eighteenth-century predecessors take the trouble to walk through the streets and visit the buildings when compiling the inscriptions? Since many of the inscriptions in the Brussels compilation were already accessible in printed form, would it not be more appropriate to regard the compilers as scholars who consulted publications rather than as urban strollers and proponents of the peripatetic method? As such, their modus operandi was very similar to the one adopted by ancient historians, who were compilers who availed themselves of other people's records as well as their own observations, and who might not personally have seen the inscriptions in question. ${ }^{80}$ Indeed, Buonocore firmly concluded that it was much more common for epigraphic documents to be copied from earlier accounts than to be recorded 'in the form

\footnotetext{
77 Appendix 1, Nos. 21, 25, 27, 37, 40, 42, 43, 44, 45, 47 and 48.

78 Description de la ville de Bruxelles (Brussels 1743), p. 95.

79 Appendix 1, Nos. 16, 17, 21, 25, 29, 37, 38, 39, 40, 42, 43, 44, 45, 47, 48 and 49.

8o Davies, art. cit. (n. 9), p. 376.
} 
in which the observer had read and understood them'. ${ }^{81}$ Even in the nineteenth century, when a more scientific study of epigraphic sources gradually developed and the authenticity question started to become an issue, urban historians such as Henne and Wauters as well as the compilers of the first volumes of the Corpus Inscriptionum Latinarum still consulted a wide range of printed publications, manuscripts, and export documents. ${ }^{82}$

\section{Conclusion}

In the late seventeenth century, Dutch illustrator Jan Luyken produced the frontispiece for the second edition of Edward Browne's Naauwkeurige en gedenkwaardige reysen ('Accurate and memorable travels'), published in Amsterdam in 1698 by Jan ten Hoorn (Fig. 5). ${ }^{83}$ In the background a horseman is seen talking to another man in a town, while in the foreground a group of men are reading, studying, and discussing a collection of books, maps, and a globe. The scene may refer to the preparations necessary before undertaking a journey, but it is equally possible that these men are carrying out preliminary work for the compilation of a travelogue or topography. ${ }^{84}$ The British physician Edward Browne (1644-1708) actually did both, and we may assume that he read and used many books while planning his travels and preparing his publications.

In this article we have argued that the hand-written compilation containing the texts of fifty-two public inscriptions from eighteenth-century Brussels provides a glimpse of such preparations for a town description or history. Unfortunately we were unable to find or identify a publication in which all of the recorded inscriptions appear together. It is likely that this book was never published; many similar undertakings are known to have been abandoned. Why and how the hand-written compilation survived is unknown. Nonetheless the information it contains is of particular interest to local historians and archaeologists studying the history, architecture, and significance of Brussels' public and private buildings. The compilation presents and comments on a range of

\footnotetext{
81 Buonocore, art. cit. (n. 11), p. 22.

82 Davies, art. cit. (n. 9), p. 376.

83 Naauwkeurige en gedenkwaardige reysen van Edward Brown M. Dr... door Nederland, Duytsland, Hongaryen, Serbien, Bulgarien, Macedonien, Thessalien, Oostenr., Stierin., Carinthien, Carniole en Friuli, enz. (Amsterdam 1696); see also P. van Eeghen and J.P. van der Kellen, Het werk van Jan en Casper Luyken (Amsterdam 1905-19o6), vol. 1, p. 7 (Cat. No. 49).
}

84 We owe this last hypothesis to Marissa Griffioen; see M. Griffioen, Kaartgebruik in beeld. De relatie tussen verbeeld en werkelijk kaartgebruik op de prenten van Jan en Casper Luyken (University of Amsterdam 2019, unpublished master's thesis), p. 29. 


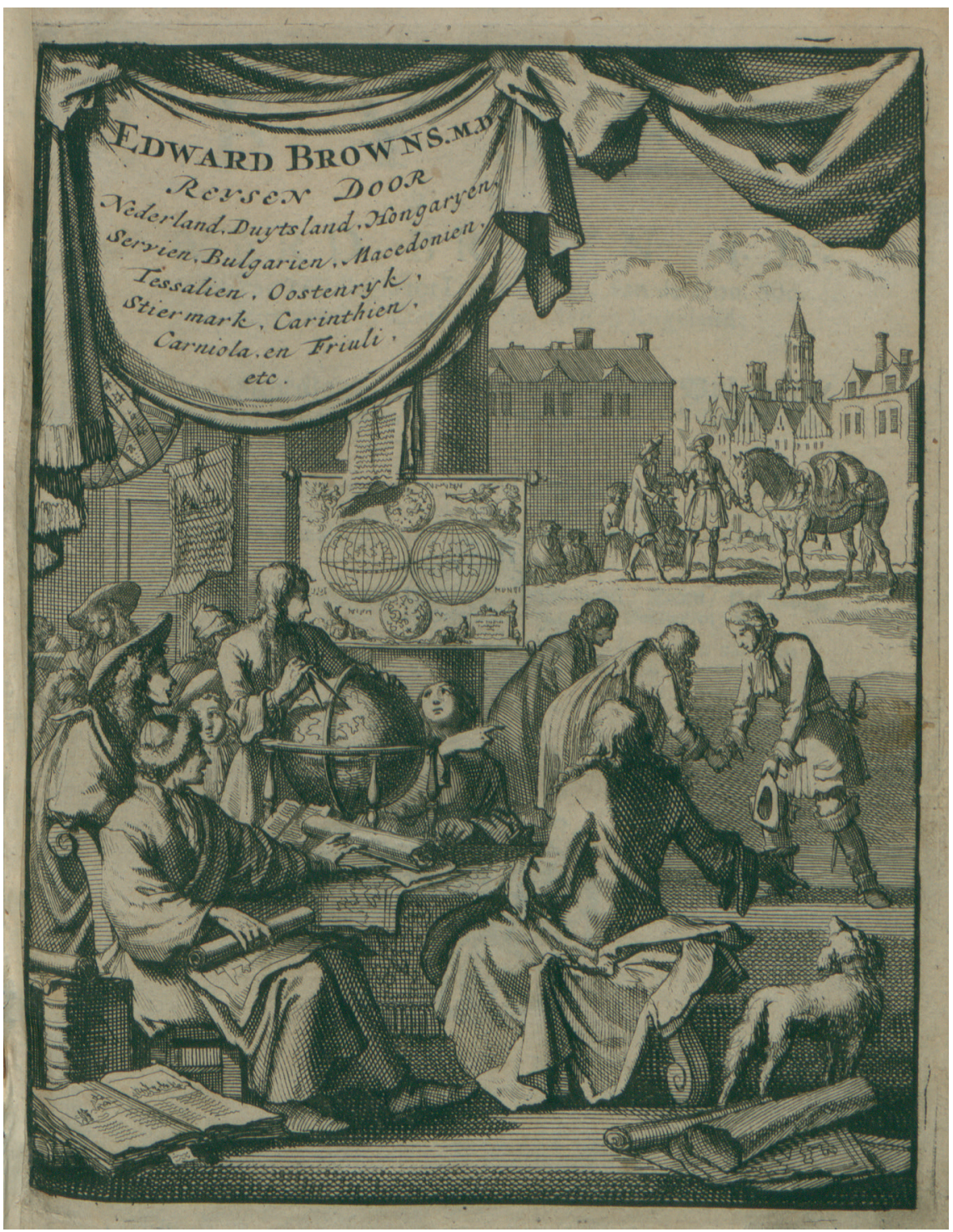

FIGURE 5 Jan Luyken's cover print of Edward Browne's Naauwkeurige en gedenkwaardige reysen, published in Amsterdam by Jan ten Hoorn in 1696 AMSTERDAM, AMSTERDAM MUSEUM, INV.NR. A 43603 
public texts that appear to have been recorded in the late eighteenth century. Most of them perished together with the buildings to which they were once attached, in some cases long before that time.

Nonetheless, scholars also need to look beyond the superficial documentary value of such compilations and to approach them with caution. Even if the documentation is poor it is essential to scrutinize the textual transmission of public inscriptions and the methods by which early modern antiquarians collected and compiled information for their travelogues and topographies. In this particular instance, the different handwritings indicate that the preliminary notes were not the work of a single person but a collective undertaking, as is also suggested by Jan Luyken's illustration. While the authors suggest that they recorded the texts in the course of walks around town it is certain that they also copied texts from existing travelogues, town descriptions, and town histories. At least twenty inscriptions in the compilation had already been published in sixteenth-, seventeenth- and eighteenth-century books. The compilation thus reveals which publications were consulted by the Brussels intelligentsia, but it also testifies to the existence of what might be called a 'canon of public inscriptions', that is: a coherent set of striking, recurring public texts that were copied and published over and over again. Despite its documentary value, the Brussels compilation of inscriptions probably reveals more about the spread of this canon by means of various types of publication than about which texts were publicly accessible in the Brussels cityscape in the late eighteenth century. 


\section{Appendix 1: Summary, Transcriptions and Translations of the Inscriptions relevées sur les façades des églises, couvents, hôpitaux et maisons de Bruxelles ${ }^{\text {a }}$}

No. Building Date Original text

Inscriptions relevées sur les façades des églises, couvents, hôpitaux et maisons de Bruxelles.

Inscriptions qu'on trouve sur les facades des eglises, couvents et maisons pieuses et hopitaux.

Philip Amrhein [?] opgerecht de Gelaese Blakerije.

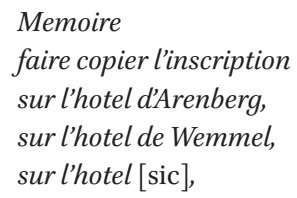

Chapitre inscriptions detruittes ou supprimées.

Inscription placée dans la collegiale a la chapelle du St. Sacrement de Miracles. Quisquis ades, summi tangit quem cura tonantis; dum properas, coeptum siste, viator, iter. Haec tibi viva caro, aeterni sapientia Patris Christus adest, vivus panis, et una salus. Invida judaeûm quam dum laniare laborat impietas, meritis ignibus ecce ruit. Quare age, divinos huic funde, viator, honores; funde Deo dignas supplice mente preces. 
2o July 1743 .

Philip Amrhein [?] [has] erected De Glazen Blekerij.

Come all ye who are touched by the care of the Most High; traveller, while you speed along, pause on your way; this to you is living flesh, the wisdom of the eternal Father; Christ is present, the living bread and sole salvation; see, that which the blasphemy of the Jews tried to destroy in envy, instead brought them down in justified flames; therefore, traveller, act and bring divine homage to this, and in a meek spirit pour out appropriate prayers to God.
Guicciardini, 1567 , p. 57; De Boeck, 1770, vol. II, p. 26 (transl.); Rombaut, 1777-1779, vol. I, pp. 211-212;

De Mengin-Fondragon, 1843, p. 102. 
Appendix 1 (cont.)

No. Building Date Original text

$\begin{array}{ll}\text { St. Gudula } & 1370 \text { and } \\ \text { Church } & 1639\end{array}$

Inscription placée dans la meme chapelle.

Stupendum supra omnia miraculum: miraculum perpetuum; tres hostiae sacrae anno Christi 1370 ab impiis judaeis sacrilege surreptae, et pugionibus (proh nefas!) confossae, sanguinem effuderunt, nec latuit abominandum scelus. De judeis igne supplicium sumptum sacrae hostiae in D. Gudulae aede principe populorum veneratione expositae, et prodigiosis in mortales beneficium $^{\mathrm{d}}$ inclytae, mortuis vitam, caelis [sic, caecis] visum, claudis gressum, aliis alia subsidia contulêre. Atque etiam num supersunt divina pignora, ${ }^{\mathrm{e}}$ et tam veterum plagarum vestigiis, quam illaesis post tot lustra plagarum formis admiranda. Bruxellae adorantur MDCXXXIX. SS. Eucharistiae Otto Zylius è Soc.Jesu D.N.M.Q.E.P. [Devotus ${ }^{\mathrm{f}}$ Numini Majestatique Ejus Publice]. De seven adelborsten in Brussel geprivilegeert, in luyster en splendeur geexalteert, hebben dit gelas hier t'saemen vereert, daer Sleeuws eerste van adel was gepresenteert, Rodenbeeck den tweeden in dées edel bende, de derde t'Serroelofs de wel bekende, t'vierde Coudenberch seer vroom ende milde, t'vijfde t'Steenweghs metter schelpen schilde, den sesden t'Serhuygs die niemant moet wijcken, en Sweerts daer en boven. Dit sijn al gelyckx, die tot Godts eeren dit gelas hebben gegeven in't jaer duysent drij hondert tachentigh seven, verwachtende hier naer het eeuwigh leven. S. Michiel ende S. Goedele hebben sij doen stellen, ter eeren Godts, spijt den duyvel der hellen.

Inscription gravée sur la piramide errigée en 1568 sur le terrein qu'occupoit l'hotel de Cuylenbourg rasée la meme année.

Regnante Philippo II cathol[ico] Hispan[iarum] rege in his suis Inferioris Germaniae regionibus, gubernante vero ejus nomine Ferdinando Alvarez de Toledo, Alvae duce etc., Florentii de Pallant, comitis Culenburg, quondam domum solo aequari sancitum est, ob execrandam memoriam repetitae in ea conjurationis adversus religionem Ecclesiae Cathol[icae] Rom [anae], regiam majestatem, et ipsas regiones. Anno a salute CID.D.L.XVIII. quinto kalend. junii. 
More amazing than any other miracle, the eternal miracle. In the year 1370, three consecrated wafers, sacrilegiously stolen by blasphemous Jews, and by them (alas!) pierced by daggers, shed blood. And the heinous crime did not remain hidden. After the Jews had been brought to justice with fire, the sacred Hosts were displayed for popular veneration in the main church, St. Gudula, where they became famous by the miraculous blessings they bestowed upon mortals: to the dead, they gave life; to the blind, sight; cripples could walk again, and to others they gave yet other gifts. And the divine tokens still exist and should be revered, both for the traces of the old wounds and for the untarnished beauty of these wounds after so many lustrums. In Brussels, they are being worshipped in 1639 at [the altar of] the Most Blessed Sacrament. Otho Zylius, Jesuit. Publicly dedicated to the Godhead and His glory.

The seven noblemen, favoured in Brussels, exalted in glory and splendour, together honoured this glass, among whom Sleeuws was the first to be ennobled, Rodenbeeck the second in this noble group, t'Serroelofs the third, the well-known, Coudenberg the fourth, pious and kind, t'Steenweegs the fifth, with scallops on their coat of arms, t'Serhuygs the sixth, who yield to no-one, and above all Sweerts. These together, to the glory of God, donated this glass window in the year 1387 in the expectation of eternal life. They also commissioned the [glass windows of] St. Michael's and St. Gudula's, to the glory of God, and in contempt of the devil in hell.

While Philip II, Roman Catholic King of Spain, ruled over his Netherlands, and Ferdinand Alvarez de Toledo, Duke of Alba etcetera was viceroy, orders came that the residence of Florens de Pallant, Count of Culemborg, should be razed to the ground as a despicable reminder of the repeated plotting in this [house] against the religion of the Catholic Roman Church, against His Royal Majesty, and against his realm. In the year of our salvation 1568, 28 May.
Christyn, 1677 , pp. 40-41; Sanderus, 1726-1727, vol. III, p. 238; Basilica Bruxellensis, 1743, p. 61; Collection of voyages and travels, 1732, vol. VI, p. 374; De Boeck, 1770, vol. II, pp. 24-25 (transl.); Rombaut, 1777-1779, vol. I, pp. 210-211.

Christyn, 1677 , pp. 39-40; Basilica Bruxellensis, 1743 , pp. 6o-61; De Boeck, 1770, vol. II, p. 9; Rombaut, 1777-1779, vol. I, p. 96.
Van Meteren, 1593, vol. III, p. 12; Dujardin, 1757-1770, vol. v, p. 198; Henne and Wauters, 1845 , vol. I, p. 416 (French transl.). 
Appendix 1 (cont.)

\begin{tabular}{|c|c|c|c|}
\hline No. & Building & Date & Original text \\
\hline 6 & $\begin{array}{l}\text { Fish- } \\
\text { mongers' } \\
\text { Guildhall }\end{array}$ & 1639 & $\begin{array}{l}\text { Inscription sur la facade orientale de la sale d'assemblé du corps de marchands } \\
\text { de poisson. } \\
\text { Philippo Quarto Hispaniae rege et Brabantiae duce collegium hic tyopolarum } \\
\text { salariorum aere suo opus hoc ad aeternam gratiam à fundamentis faciendum } \\
\text { curavit. Bruxellis anno } 1639 \text {. } \\
\text { Nota. Fut abbatu en } 177[\text { o] par ordre du corps de marchands de poissons par } \\
\text { Vanderhaegen, sculpteur, quand il [sic, ils] firent des reparations a cette maison } \\
\text { à l'occasion du jubile [sic, jubilé] de } 400 \text { ans du St. Sacrement de Miracles. }\end{array}$ \\
\hline
\end{tabular}

$7 \quad$ Statue of

Maximilien-

Emmanuel

of Bavaria

on the

Brewers'

Guildhall

8

Small

1702

Butchers

Guildhall

9

Cannon

10

Fountain

1717

in Kouden-

berg Park
Inscription sous la figure equestre de Maximilien Emanuel, electeur et duc de Bavière, gouverneur general des Pays Bas.

Dux Bavariae Bruxellensium salus.

Dum premeret radiis nostram sol Gallicus urbem

te solum in maestos vidimus ire rogos.

Quid mirum Geticae qui fregit cornua lunae

Gallica si solis lumina non metuat?

Inscription sur la facade [de] la Petitte Boucherie, à present la Sale

du Concert Bourgois.

HIspanIae MonarCha ConDebat.

Inscription sur le piedestal, sur lequel etoit un canon de fer \#.

Dederitne viam casusve, Deusve? Mirabili certe casu, hostilis navis, tormentis regiis perforata, cum accenso pulvere crepuisset, hoc tormentum et una juvenculam altè sublatam in regis pretoria deposuit. Adéo tutum in Rege non solum innocentia sed etiam suplex hostilitas perfugium habet. Isabella Clara Eugenia, Belgii princeps. ${ }^{\mathrm{g}}$ \# Nota. Ce Canon etoit place [sic, placé] au bas de lescalier qui conduisoit au petit parc du coté de labbaye de Caudenberg. Le piedestal etoit de marbre. Nota. Ce Canon fut vendu en 177: [sic] pour la somme de ... florins, il pesoit ... livres. Nota .........., aubergiste demeurant pres le pont St. Michel lacheta.

Nota. Il fut fondu dans la fonderie de ......... à ......

Inscription que le czar Pierre I a gravé sur le bord d'un bassin d'une fontaine dans le parcq du palais à Bruxelles doutil trouvoit l'eau si bonne qu'il l'a preferrat au vin. Petrus Alexiowits czar, magnus Muscoviae dux, insidens margini hujus fontis aquam illius nobilitavit libato vino horâ post meridiem tertiâ die 16. aprilis anni 1717. 
Under Philip IV, King of Spain and Duke of Brabant, the sea-fishmongers guild, with his money, commissioned this work from its foundations [as a token of] everlasting gratitude. Brussels, in the year 1639 .

The Duke of Bavaria, Brussels' salvation.

When the French sun pierced our city with its rays, we saw you alone ascend the sad pyres. Small wonder, that he who shattered the horns of the Getian moon has no fear of the light of the French sun.

The King of Spain established [this].

Was it mere chance or divine intervention? Certainly, a miraculous affair. When a hostile vessel was pierced by the royal cannons and the lit gunpowder exploded, a cannon and a young girl were thrown high up and deposited in the royal palace. Thus, not only innocence found shelter in the royal [palace] but also the humbled enemy found refuge there. Isabella Clara Eugenia, princess of Belgium.

Csar Peter Alexeyevich, Grand duke of Moscow, whilst seated beside this fountain, bestowed a knighthood upon its water by pouring wine into it. [This happened] in the third hour after noon, on 16 April, 1717.
Henne and Wauters, 1845 , vol. III, pp. 188-189.

Sturm, 1719, p. 45;

Description, 1743, p. 45;

Genius der Zeit, 180o, p. 928;

Henne and Wauters, 1845 , vol. III, p. 54.

Description, 1743, p. 126;

Historie, 1791, pp. 21-22;

Henne and Wauters, 1845 , vol. III, p. 151.

Misson, 1691, vol. II, p. 259; Berkenmeyer, 1729, vol. I, p. 174; De Reiffenberg, 1825-1827, vol. I, pp. 100-101.
Stuart, 1814-1822, jg. 1815 , p. 125; Smithers, 1818, p. 29; Van de Vijver, 1823 , p. 22 (transl.); Henne and Wauters, 1845 , vol. III, p. 334 . 
Appendix 1 (cont.)

\begin{tabular}{|c|c|c|c|}
\hline No. & Building & Date & Original text \\
\hline 11 & $\begin{array}{l}\text { T’Serclaes } \\
\text { Hospice }\end{array}$ & 1623 & $\begin{array}{l}\text { Inscription audessus de la porte de la maison pieuse. } \\
\text { A l'honneur de Dieu et de madame } S^{t} \text { Anne et noble Damme Anne t'Serclaes } \\
\text { etant aliee a mes }[\text { si] }[\text { [e] Fr }[\text { ançois] de Haynin, ch[eva]l[i]er, seigneur de la } \\
\text { Bernierre [sic, Berlières] et du Fresnelle. Laditte Damme a fait batir ceste } \\
\text { hopital lan } 1623 .\end{array}$ \\
\hline 12 & $\begin{array}{l}\text { Church } \\
\text { of Our } \\
\text { Lady of } \\
\text { Montserrat }\end{array}$ & & $\begin{array}{l}\text { Inscription sur la facade de leglise de Notre Dame de Mont Serrat } \\
\text { D. Mariae de Monte Serrato Sacrum. }\end{array}$ \\
\hline 13 & $\begin{array}{l}\text { Hospice } \\
\text { for six } \\
\text { poor } \\
\text { women }\end{array}$ & 1636 & $\begin{array}{l}\text { Inscription qui se trouve sur la maison pieuse pres des sœurs noir }[s] \text {. } \\
\text { Godtshuys ende fonddatie Gillis vanden Bempde ende Jouffrouwe Margriete } \\
\text { vander Reest voor sesse arme vroukens } 1636 \text {. }\end{array}$ \\
\hline 14 & $\begin{array}{l}\text { Jesuit } \\
\text { Church }\end{array}$ & & $\begin{array}{l}\text { Inscriptions sur la facade de leglise de }[\text { s }] \text { jesuîttes. } \\
\text { Ad maiorem Dei gloriam. S. Michaëli Sacrum gaudent angeli aedificatum } \\
\text { restauratum. }\end{array}$ \\
\hline 15 & $\begin{array}{l}\text { Jesuit } \\
\text { Church }\end{array}$ & & $\begin{array}{l}\text { Inscriptions sur la facade de léglise de }[\text { s] jesuittes. } \\
\text { Ad majorem dei Gloriam. Gaudent angeli aedificatum } \\
\text { restauratum. }{ }^{\mathrm{h}}\end{array}$ \\
\hline 16 & $\begin{array}{l}\text { Military } \\
\text { hospital }\end{array}$ & 1727 & $\begin{array}{l}\text { Inscription sur la porte de l'hopital militaire. } \\
\text { pUbLICae tranqUILLItatI paUpertatIs otIoseqUe pLebIs UtILe refUgIUM: } \\
\text { eLIsabethae LIberaLItate SenatUs PopULUsqUe brUXeLLensIs P.P. }{ }^{\mathrm{i}}\end{array}$ \\
\hline 17 & $\begin{array}{l}\text { Military } \\
\text { hospital }\end{array}$ & & $\begin{array}{l}\text { Caesaris auspiciis per te, hospite, surgit in altum pro patriae votis, Elisabetha } \\
\text { domus. Quotquot saxa vides, totidem tua munera cernis, et cura populi signa } \\
\text { notasque tui. Dum stabit Bruxella, suae pia facta parentis et grata nomen } \\
\text { posteritate canet. }\end{array}$ \\
\hline
\end{tabular}

$18 \begin{array}{ll}\text { Military } & 1559 \text { and } \\ \text { hospital } & 1638\end{array}$

Aegidius de Breusseghem Canonicus Anderlechtensis fundavit Bruxellis singulis hebdomadibus erogationem panis pauperibus. A dextris depictus cernitur in aula fundationis habitu Canonicali indutus, flectens ante imaginem Beatae Virginis. In frontispicio domus legitur sequens inscriptio: Domus Beatae Mariae Virgini sacra fundata a Nostro Domino AEgidio de Breuseghem presbytero $A^{o}$ 1559 aucta a Domina Maria de Busleijden, Domini Caroli l'Archier a Consilio et Rao $^{\text {bus }}$ [Rationibus?] suae Majestati in Brabantiae, vidua $A^{\circ}{ }_{1} 638$.

N.B. Fundatio haec postea unita fuit Mensae Sancti Spiritûs Parochiae S.S. Michaëlis et Gudulae. 
Sacred to Our Lady Mary of Montserrat.

Hospice and foundation by Gillis vanden Bempde and Lady Margriete vander Reest, for six poor women, 1636 .

To the greater glory of God. The angels rejoice St. Michael's Church is built and restored.

To the greater glory of God. The angels rejoice that this is built and restored.

A useful refuge for public tranquility from poverty and idle people, the senate and people of Brussels did publicly build, by the generosity of Elisabeth.

For you, visitor, soars high, under imperial auspices [this] house of Elisabeth, redeeming a pledge to the nation. The number of stones you see equals the favours to you you observe and the number of signs, by the care of your people, you notice. As long as Brussels will exist shall her [i.e. Elisabeth's] pious deeds and her name resound to grateful posterity.

Aegidius of Breusseghem, canon of Anderlecht, established a weekly distribution of bread to the poor in Brussels. He can be seen in the foundation's hall, to the right, dressed in a canon's habit, kneeling to an image of the Blessed Virgin. On the cornice of the house the following inscription may be read: This house, dedicated to the Blessed Virgin Mary, was established by Our Lord Aegidius of Breuseghem, priest, in the year 1559. [The house] was enlarged by Lady Mary of Busleyden, widow of Lord Charles l'Archier, councillor and comptroller to His Majesty in Brabant, in the year 1638. Take notice. This foundation later merged with the Table of the Holy Ghost of the parish of St. Michael and St. Gudula.

Henne and Wauters, 1845 , vol. III, p. 546.

Henne and Wauters, 1845 , vol. III, p. 546. 
Appendix 1 (cont.)

\begin{tabular}{|c|c|c|c|}
\hline No. & Building & Date & Original text \\
\hline 19 & $\begin{array}{l}\text { Jesuit } \\
\text { Church }\end{array}$ & & $\begin{array}{l}\text { Inscription dans leglise de jesuittes, placée au milieu du sanctuaire audessus du } \\
\text { maitre autel pres la voute. } \\
\text { D.o.M. [Deo Optimo Maximoque] Serenissimis archiducibus Albertus et } \\
\text { Isabella. }\end{array}$ \\
\hline 20 & $\begin{array}{l}\text { Church } \\
\text { of the } \\
\text { Barefoot } \\
\text { Carmelites }\end{array}$ & 1620 & $\begin{array}{l}\text { Epitaphium. } \\
\text { Don Rodericus Nino de Losa, Comes de Anover, SanctiJacobi militiae } \\
\text { commendator de Mantiel et Laossa, Philippi III. Hispaniarum regis e } \\
\text { consiliis belli supremis, regiae Toletanae monetarum domus thesaurarius. } \\
\text { Serenissimorum } \\
\text { archiducum Alberti et Isabellee [sic] magnus oeconomus, magnus equorum } \\
\text { magister serenissimique archiducis summus a cubiculis. Rexit pro votis Dei, } \\
\text { obiit pro voto suo die Beatae matris Theresiae v octobris anno MDCXX. Qui } \\
\text { sacro isto loco depositus. } \\
\text { Derrier le tableau du triomphe de la Ste Eglise dans l'Eglise des Carmes } \\
\text { dechaussés à Bruxelles. }\end{array}$ \\
\hline 21 & $\begin{array}{l}\text { Town } \\
\text { house of } \\
\text { Rubempré }\end{array}$ & & $\begin{array}{l}\text { Inscriptions sur la porte de l'hotel de Rubempré. } \\
\text { Donat virtuti à Caelo victoria palmam. Virtus felices, credite, sola facit. } \\
\text { A me-Invidiam. Virtus. Invidiosa-Per me. }\end{array}$ \\
\hline 22 & $\begin{array}{l}\text { La } \\
\text { Renommée / } \\
\text { De Faam }\end{array}$ & & $\begin{array}{l}\text { Cabaret ...j appelé la Renommee ........ } N^{\circ} 13 \\
\text { Inscription sur la porte d'une maison Grande Place nommée Crescit eundo. }\end{array}$ \\
\hline 23 & $\begin{array}{l}\text { House on } \\
\text { Konings } \\
\text { Street, } \\
\text { near the } \\
\text { Park }\end{array}$ & $\begin{array}{l}1777 \text { or } \\
1787\end{array}$ & $\begin{array}{l}\text { Sur un hotel situé rue Royale au Parc formant deux habitations separées } \\
\text { portant les } N^{\text {os }} 30 \text { et } 32 \text { habités la premiere par le comte de Cornelissen la } \\
\text { seconde par ........... } \\
\text { Ludovicus Massian, Ludovici filius, primum lapidem posuit anno sallutis } \\
\text { [sic, salutis] MDCCLXXVII. } \\
1787 .\end{array}$ \\
\hline 24 & $\begin{array}{l}\text { Royal } \\
\text { Library }\end{array}$ & 1754 & 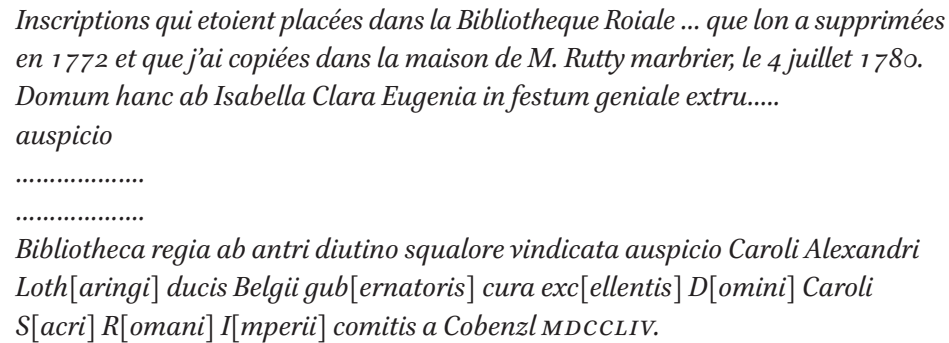 \\
\hline
\end{tabular}


To the highest and greatest God. By the Most Serene Archdukes Albert and Isabella.

Epitaph.

Don Rodrigo Nino y Lasso, Count of Anover, Commander of Mantiel and Laossa in the Knighthood of St. James, under Philip III, King of Spain; [member of] the Supreme Council of War, and Treasurer of the Royal Mint

at Toledo; mayordomo mayor and caballerizo mayor to the Most Serene Archdukes Albert and Isabella, and sumiller de corps to the Most Serene Archduke. He reigned whilst keeping his vows to God, and died whilst keeping his vow, on the day of the Blessed Mother Teresa [of Avila], 5 October, in the year 1620. He was laid in this sacred place.

Victory gives the palm from heaven to the virtue. Only virtue makes all happy, believe ye it.

By me-Envy. Virtue. Envious-Through me.

Description, 1743, pp. 94-95;

Guide fidele, 1761, p. 35; Henne and Wauters, 1845 , vol. III, p. 379 .

She [i.e. Fame] grew by going.

Louis Massian, son of Louis, laid the first stone In the year of our salvation 1777 .

1787 .

This house by Isabella Clara Eugenia on the occasion of the wedding ........ under the auspices

The Royal Library was conquered on the lengthy squalor of the cave, under the auspices of Charles Alexander, Duke of Lorraine and Viceroy of Belgium, by the care of the Most Excellent Lord Charles, Count of Koblenz, of the Holy Roman Empire 1754. 
Appendix 1 (cont.)

\begin{tabular}{|c|c|c|c|}
\hline No. & Building & Date & Original text \\
\hline 25 & $\begin{array}{l}\text { Small } \\
\text { Butchers } \\
\text { Guildhall }\end{array}$ & 1702 & $\begin{array}{l}1702 . \\
\text { In den gevel van het nieuwt gebaut Klyn Vleeshuys in de Beijerstraet stont: } \\
\text { hIspanIae MonarCha ConDebat. } \\
\text { Luijdende in onse tael: Den SpaensChen KonIng MaeCkte DIt. teweten Koni }\end{array}$ \\
\hline 26 & $\begin{array}{l}\text { House of } \\
\text { the late Mr. } \\
\text { Pangaert on } \\
\text { Korenmarkt } \\
\text { Square }\end{array}$ & & $\begin{array}{l}\text { Inscription sur la cour interrieure de la maison occupé par feu Mr. Pangae } \\
\text { le Marché au Bled. } \\
\text { Qui me errexit [sic, erexit] accurate direxit. }\end{array}$ \\
\hline 27 & $\begin{array}{l}\text { House } \\
\text { built on } \\
\text { the site of } \\
\text { the former } \\
\text { Steenpoort } \\
\text { Prison }\end{array}$ & 1760 & $\begin{array}{l}\text { Inscription sur une de }[s] \text { maisons baties sur le terrein qu'occupoit la priso } \\
\text { Steenpoorte. } \\
\text { tanDeMpULCher faCtUs. }\end{array}$ \\
\hline 28 & $\begin{array}{l}\text { Secret } \\
\text { Council }\end{array}$ & 1771 & $\begin{array}{l}\text { Inscription qui à eté placée sur le Conseil Privé lorsqu'il a ete rebatie. } \\
\text { Auspicio et impensa Mariae Theresiae aug[ustae] Carolo Alexandro } \\
\text { Lotharingico Provinciis inferioris Germaniae praefecto Georgio S[acri] } \\
R[\text { omani] }[\text { [mperii] principe Starhemberg Regni per easdem provincias } \\
\text { administro aedes haec Belgicarum legibus sanciendis sacra in meliorem } \\
\text { formam restituta Procurante Patritio comite de Neny Sanctioris Consilii } \\
\text { Praeside M.D.C.C.L.X.X.I. }\end{array}$ \\
\hline
\end{tabular}

29 Canal

Inscription placee sous l'horloge au bureau d'embarquement sur le Canal.

Office Utere praesenti memor ultimae.

$30 \quad$ House on 1779

Vissers

Inscriptie staende op een huys op de Visschers Zenne 1779

Zenne

Dit huys

inde Draeck

is goet en

sinne [?] is

bequaem

synen naem.

$31 \quad$ House in

Inscription sur une pierre massonnée sur la facade dune maison dans la Rue de Zespenningen Six Jettons (Sespenning straete) presque vis à vis la chapelle de St Charles Boromé.

Street Rerum irrecuperabilium optima res est oblivio. 
On the façade of the recently built Klein Vleeshuis in Beijer Street was written: Historie, 1791, pp. 21-22; hIspanIae MonarCha ConDebat.

Which in our language is: The King of Spain established this, To wit, King ... Henne and Wauters, 1845 , vol. III, p. 151 .

He who built me gave accurate directions.

At last made beautiful.

Guide fidèle, 1761, p. 48; Description, 1782 , p. viii.

Under the auspices and at the expense of the August Lady Mary Teresa, [and] while Charles Alexander of Lorraine was viceroy of the Low Countries [and] while George Prince of Starhemberg of the Holy Roman Empire was minister plenipotentiary of these same provinces, this house, dedicated to the upholding of the laws of the Belgians, was restored to its former glory, by the care of Patrice, Count of Neny, leader of the Privy Council. 1771.

Use well the present [hour], remember the final [hour].

Henne and Wauters, 1845 , vol. III, p. 524 .

Inscription on a house on Vissers Zenne 1779

This house

In the Dragon

is good and

... [?] is

able

its name.

In matters that are beyond repair, oblivion is best. 
Appendix 1 (cont.)

\begin{tabular}{|c|c|c|c|}
\hline No. & Building & Date & Original text \\
\hline $3^{2}$ & $\begin{array}{l}\text { House of } \\
\text { Mr. van } \\
\text { Laethem } \\
\text { on Zavel } \\
\text { Square }\end{array}$ & 1682 & $\begin{array}{l}\text { Inscription placée en } 1682 \text { dans un cordon audessus de la porte d'entrée de l } \\
\text { maison habité par Mr. van Laethem sur la place du Sablon. } \\
\text { Omnium catena amor vitae. }\end{array}$ \\
\hline 33 & $\begin{array}{l}\text { House in } \\
\text { Kathedraal } \\
\text { Street }\end{array}$ & 1545 & $\begin{array}{l}\text { Inscription sur les maisons de Bruxelles. } \\
\text { On remarque sur une maison occupé ... [par?] un marchand de bois rue de lc } \\
\text { Cathedrale le millesime de } 1545 .\end{array}$ \\
\hline 34 & $\begin{array}{l}\text { House of } \\
\text { St. Gertrude } \\
\text { Hospice }\end{array}$ & 1678 & $\begin{array}{l}\text { Un peu plus haut sur un batimen }[t] \text { faisan }[t] \text { partie de l'hospice de St } \\
\text { Gertrude... } 1678 \text {. }\end{array}$ \\
\hline 35 & $\begin{array}{l}\text { House } \\
\text { of the } \\
\text { messenger } \\
\text { Briard in } \\
\text { Gasthuis } \\
\text { Street }\end{array}$ & 1667 & $\begin{array}{l}\text { Sur les deux cotes de la porte d'une maison rue de lHopital occupée par les } \\
\text { messagier [?] Briard et anterieuremen[t] par le sellier Bertels. Anno } 1667 .\end{array}$ \\
\hline
\end{tabular}

$36 \quad$ St. Gudula $\quad 1783$ Church

Affige le 22 mars 1783 sur l'Eglise de St Gidule [sic] a Bruxelles lorsque Joseph 2 etoit reignant.

Opposé vous Belgique à l'esprit heretique de votre empereur dont Luther et Calvin ont bleszé le cour.

Ce canon fut vendu publiquement en $177^{\circ}$ a Mr Baudenyns [sic] aubergiste pres du Pont de St Michiel pour 19 florins.

[3] medailles dans les fondements de la chapelle de la Court.

mv bisat fui

met: de holl

supplement

Aen Brusselmans tot Willebrouk tegen 2 oorden het pont is 400 pondt desen van heeft het verckocht [sic].

Ende kleercooper \# Eyves Huygens neffens de Gebrilde Roey den joncksten gieter aen een gieter tot Koukelberg op den wegh van Dilegem het is gegoten.

Het git van't canon wegende 400 pont is voor ballast over dry a vier weeken naer Holland gesonden.

Het canon weghde..... pondt.

Chapitre inscriptions sur des fontaines publiques. 
Love of life links [us] all.

To Brusselmans [residing] at Willebroek, at 2 farthing the pound, makes 400 pounds, from has sold it [sic].

And clothes dealer Eyves Huygens [residing] next to the [house called]

Gebrilde Roede [?], the youngest caster, to a caster [residing] at Koekelberg on the road from Dielegem, it has been cast.

The jet [?] for the canon, weighing 400 pounds, has been sent to Holland as ballast over the course of three or four weeks.

The canon weighed ... pounds. 
Appendix 1 (cont.)

\begin{tabular}{|c|c|c|c|}
\hline No. & Building & Date & Original text \\
\hline 37 & $\begin{array}{l}\text { Fountain } \\
\text { on Zavel } \\
\text { Square }\end{array}$ & $\begin{array}{l}1740 \text { and } \\
175^{\circ}\end{array}$ & $\begin{array}{l}\text { Inscription sur la fontaine de la place du Sablon. } \\
\text { Thomas Bruce Comes Ailesburiensis M[agnae] Brit[anniae] par hospitio apud } \\
\text { Bruxellas XL. annis usus jucundo et salubri de suo poni testamento jussit anno } \\
\text { MDCCXL anno MDCCL Pace ubique terrarum firmata, Thomas Bruce Thomae } \\
\text { haeres erigi curavit, Francisco Lotharingo Rom [anum] imperium et Maria } \\
\text { Theresia Caroli VI filia regna paterna fortiter vindicata, feliciter et gloriose } \\
\text { tenentibus: Carolo Lotharingo Belgii gubernatore. }\end{array}$ \\
\hline
\end{tabular}

$38 \quad$ Fountain $\quad 1765$

in Hoog

Inscription sur la fontaine de la rue Haute pres leglise pariossiale de N.D. de la

Street chapelle.

near

Chapel

Church

Utilitati publicae S.P.Q.B. MDCCLXV.

Inscription sur la fontaine pres la porte de Hall.

near Halle

Plus oultre.

Gate

Sur la facade de lEntrepot.

Mercatorum commodo et securitati aedes a Maria Theresia Aug[usta] extructa $M D C C L X X X$.

41 Town

house of

Sur la porte principale de Lhotel de Merode Rue aux Laines:

Merode

Sur la maison nommée la Bourse

De Beurs

Ah! Velox furibunda exausit Francia Bursam nunc ex exusta pax solidam tribuit. 
Thomas Bruce, Earl of Aylesbury, peer of Great Britain, having enjoyed the pleasant and wholesome hospitality of Brussels for forty years, in his testament ordered this [fontain] to be built in the year 1740. In the year $175^{\circ}$, after peace had been restored everywhere in the world, Thomas Bruce, heir of Thomas, commissioned [this fontain] to be erected, while Francis of Lorraine and Mary Teresa, daughter of Charles vi, prosperously and gloriously held sway over the Roman Empire, having forcefully asserted the paternal reign, [and] while Charles of Lorraine was viceroy of Belgium.

For the common good. The senate and people of Brussels 1765 .

This house was erected by the Empress Mary Teresa for the convenience and safety of merchants, in 178 o.

Ah! Fast and raging France has burnt de Beurs [the Exchange], [but] now, from the ashes Peace has made it solid [again].
Guide fidèle, 1761, p. 38; Description des tableaux, 1779, pp. 6o-61; Description, 1782, p. 17; Mann, Abrégé, 1785 , vol. I, pp. 103-104; Henne and Wauters, 1845 , vol. III, pp. 414-415.

Henne and Wauters, 1845 , vol. III, p. 464.

Henne and Wauters, 1845 , vol. III, p. 588 .

Mann, 1785, vol. II, p. 112; Van de Vijver, 1823, p. 67; Romberg, 1824, p. 73; Henne and Wauters, 1845 , vol. III, p. 526 .

Guide fidèle, 1761, p. 24; Description, 1782, p. 53; Henne and Wauters, 1845 , vol. III, p. $5^{8 .}$ 
Appendix 1 (cont.)

\begin{tabular}{|c|c|c|c|}
\hline No. & Building & Date & Original text \\
\hline 43 & La Louve / & & Sur la maison nommée la Louve. \\
\hline
\end{tabular}

44 L'Union

Hotel

45

L'Union $\quad 1697$
Hotel

Hotel

697

Autre audesous de la porte.

Haec statuit pistor victricia signa trophaei quo Carolus plena laude secundus ovat.

Chapitre inscriptions sur des edifices publics et sur des fontaines.

46

Bread hall $\quad 1767$

Sur la maison des Boulangers aujourdhui l'hotel de L'Union. Hic quando vixit, miru [sic, mira] in pauperes pietate eluxit.

Inscriptions sur la Maison du Roi ditte het Broodt huys.
Inscription audessus de la grande porte.

Quum feliciter XXVIII. anno regnat $D[$ omina $]$ Maria Theresia semp [er] aug[usta], tot caesarum tot regum stirpis austr[iacae], unicum at ferax plurium Faustitatis publicae pignorum germen unanimo populorum decreto, vera parens patriae, pro ea sapienter Belgica moderante duce optimo Carolo Alex [andro] Lotharingico in quem inclutum sago togaque heroem, cordium hostimento, delicium singulorum, amor omnium aedes haec Regia paci sacrata ac dominiorum conservandis reique silvaticae venaticae et aquariae dicundis juribus Themidi aeque devotata L.XX.II. ab annis hostium ignibus etsi incassum labefacta magis quam unius et mox sesqui alterius seculi aetate cum extructa nunc curante $S[$ acri] Rom [ani] Imperi[i] Comite Carolo a Cobenzl plena cum potestate Caes[aris] majest[atis] administro intimo cui Belgae reip [ublicae] emolumentum quod multiplex vigilanti prudentia ampliatum debent boni publici incremento atque urbis ornamento restauratur CIJ. CC.L.X.V.II. 
As to [the fact that] I, ashes, for the third time arise more gloriously: I am a phoenix.

When he lived here, he lamented the poor with amazing piety.

Here, the baker placed the victorious signs of the trophy in which Charles II, full of praise, rejoices.

In the 28th year of the fortunate reign of the Most August Lady, Mary Teresa, of the Austrian lineage of so many kings and so many emperors, by unanimous popular decree the sole and fecund source of many tokens of public favours, the true parent of the fatherland, while in her name Belgium was being wisely administered by the excellent duke, Charles Alexander of Lorraine, the hero famous by the garb of war and the toga, the rewarder of hearts, the delight of every individual, the love of all, this royal building, sacred to peace and dedicated to the preservation of rights of ownership and to administer justice in forestry, hunting and fisheries, as well as to Themis, having been seventy-two years ago in vain overthrown by enemy fires, over a century and almost a century and a half after its construction, was restored, by the care of the count of the Holy Roman Empire, Charles of Koblenz, plenipotentiary of His Majesty the King, and his faithful servant to whom the Belgian State owes this boon, many times enlarged due to careful prudence, for the increase of the common good and as an ornament to the city. in 1267 [sic, 1767].
Sturms, 1719, p. 45;

Description, 1743, p. 51; Guide fidèle, 1761, p. 22; Descamps, 1769, p. 89; Description des tableaux, 1779, p. 71; Description, 1782 , p. 55 ; Henne and Wauters, 1845 , vol. III, p. 74 .

Description, 1743, p. 52; Guide fidèle, 1761, p. 23; Description des tableaux, 1779, p. 72; Description, 1782 , p. 56 ; Henne and Wauters, 1845 , vol. III, p. 72.

Description, 1743, p. 53; Guide fidèle, 1761, p. 23; Description des tableaux, 1779, p. 73; Description, 1782, p. 57; Henne and Wauters, 1845 , vol. III, p. 72. 
Appendix 1 (cont.)

\begin{tabular}{llll}
\hline No. & Building & Date & Original text \\
\hline 47 & Bread hall & 1625 & $\begin{array}{l}\text { Inscription sur le cordon du premier etage. } \\
\text { HIC votUM paCIs pUbLICae eLIsabeth ConseCraVIt. }\end{array}$
\end{tabular}

a The inscriptions have been sequentially numbered, to make it easier to refer to them. We have introduced modern punctuation and capitals, except in the case of chronograms. When possible, abbreviations in an inscription are written in full. Empty or illegible sections are rendered by dots. Latin and Dutch inscriptions have been provided with an English translation.

b We have not strived for an exhaustive list of editions.

c Letter-e crossed out.

d Sic, beneficiis in the published editions.

e Sic, vestigia in the published editions. 
Elisabeth dedicated this vow of public peace.

From plague, famine and war, deliver us, Mary of Peace.

Let everything change into gold for the nation.
Description, 1743, p. 46;

De Beckers, 1756, p. 106;

Guide fidèle, 1761, p. 20;

Description des tableaux, 1779, p. 73; Description, 1782 , p. 5o; Mann, Abrégé, 1785 , vol. I, p. 107; Paquet, 1813, vol. II, p. 29; Henne and Wauters, 1845, vol. III, p. 61 .

Description, 1743, p. 46; Description des tableaux, 1779, p. 73; Description, 1782, p. 51; Mann, Abrégé, 1785, vol. I, p. 107; Van de Vijver, 1823, p. 16; Henne and Wauters, 1845 , vol. III, p. 61 .

Henne and Wauters, 1845 , vol. III, p. 66 .

The shield bestows honour.

The protector of my affairs.

$\mathrm{f}$ An alternative reading is dicatus.

$\mathrm{g}$ The authors of the compilation forgot to copy the last sentence, known from other sources: in reimonumentum tormentum hic deponi, juvenculam alijussit (She [i.e. Isabella Clara Eugenia] ordered to place the cannon here in order to commemorate this event and she instructed to raise the girl).

$\mathrm{h}$ This inscription is crossed out, probably because it repeats the previous one.

i The abbreviation P.P. possibly stands for Publice Posuit.

j Word crossed out.

k These notes complete those of No. 9 . 


\section{Appendix 2: List of Seventeenth-, Eighteenth- and Nineteenth-Century Town Descriptions and Histories of Brussels}

J. de Boeck, Vier-honderd-jaerig jubilé van het hoog-weerdig en alderheyligste Sacrament van Mirakel, berustende in de Collegiale en Parochiale Kercke van de HH. Michael en Gudula, binnen de princelycke stad Brussel ... (Brussels 1770).

Description des tableaux, sculptures et autres curiosités, qui se trouvent dans la ville de Bruxelles; a l'usage des amateurs (Brussels 1779).

Description de la ville de Bruxelles (Brussels 1743).

Description de la ville de Bruxelles, enrichie du plan de la ville et de perspectives (Brussels $1782)$.

Le guide fidele, contenant la description de la ville de Bruxelles tant ancienne que moderne, celle de ses faux-bourgs \& de ses huit chefs-mayeries, savoir: Vilvorden, Grimberghe, Gaesbecke, Rode, Assche, Merchtem, Campenhout, \& Capelle. Ouvrage curieux \& utile (Brussels 1761).

A. Henne and A. Wauters, Histoire de Bruxelles (Brussels 1845).

Historie van de Alderheyligste Maget en Moeder Gods Maria, Onder den by-naem van Bystant, Geëert in haere publieke stads-kapelle binnen de princelyke stad Brussel. Met ophelderinge en redeneringe Over het begin des Christi geloofs in Spagnien, en Over het graf van S. Jacob in Galliciën (Brussels 1791).

Abbé Mann, Abrégé de l'histoire ecclésiastique, civile et naturelle de la ville de Bruxelles, et de ses environs; avec la description de ce qui s'y trouve de plus remarquable (Brussels $1785)$.

L.J.I.I. Raphael, Almanach bruxellois, dédié aux curieux \& aux amateurs, ainsi qu'à tous ceux qui voudront l'acheter; contenant une notice sommaire des monumens publics les plus remarquables érigés dans la Ville de Bruxelles; ainsi que des peintures \& sculptures les plus distinguées que renferment ces édifices; le tout rangé par ordre alphabétique, pour la facilité des recherches \& la commodité des lecteurs. Ouvrage posthume d'un voyageur, gentilhomme anglois (Brussels 1775).

J.A. Rombaut, Bruxelles illustrée, ou description chronologique et historique de cette ville, tant de son ancienneté, que de son état présent (Brussels 1777-1779).

C. Van de Vijver, Wandelingen in en om Brussel (Amsterdam 1823).

\section{Additional Town Descriptions, Town Histories and Travel Accounts}

A collection of voyages and travels, some now first printed from original manuscripts, others now first published in English (London 1732).

P.L. Berkenmeyer, Le curieux antiquaire, ou recueil geographique et historique des choses les plus remarquables qu'on trouve dans les quatre Parties de l'Univers (Leiden 1729).

J. de Beckers, Description historique, chronologique et geographique du Duché de Brabant, contenant: les quatre chef-villes de ce Duché, \& tout ce qui en dépend; comme aussi la description du Marquisat d'Anvers, de la Seigneurerie de Malines \& 
du Wallon-Brabant; le tout recueilli des meilleurs auteurs, tant anciens que modernes (Brussels 1756).

P.C.J. de Mengin-Fondragon, La Belgique et l'Allemagne (Paris 1843).

F.A.F. de Reiffenberg, Archives philologiques (Paris 1825-1827).

J.B. Descamps, Voyage pittoresque de la Flandre et du Brabant, avec des réflexions relativement aux arts et quelques gravures (Paris 1769).

Der Genius der Zeit. Ein Journal herausgegeben von August Hennings (Altona 180o, vol. 21).

B. Dujardin, Histoire générale des Provinces-Unies, dédiée à Monseigneur le Duc d'Orléans, Premier Prince du Sang (Paris 1757-1770).

L. Guicciardini, Descrittione di M. Lodovico Guicciardini patritio fiorentino, di tutti i Paesi Bassi, altrimenti detti Germania Inferiore (Antwerp 1567).

F.M. Misson, Nouveau Voyage d'Italie, Fait en l'année 1688. Avec un memoire contenant des avis utiles à ceux qui voudront faire le mesme (The Hague 1691).

S. Paquet, Voyage historique et pittoresque fait dans les ci-devant Pays-Bas, et dans quelques départemens voisins, pendant les années 1811, 1812 et 1813 (Paris 1813).

A. Sanderus, Chorographia sacra Brabantice, sive celebrium aliquot in ea provincia abbatiarum, coenobiorum, monasteriorum, ecclesiarum, piarumque fundationum descriptio ... (The Hague 1726-1727).

A. Sanderus, Regia domus Belgica, s. Palatium Bruxellense, cum aliis Brabantiae et Flandriae castellis (Brussels 1659).

H. Smithers, Observations made during a tour in 1816 and 1817: through that part of the Netherlands, which comprises Ostend, Bruges, Ghent, Brussels, Malines \& Antwerp ... (Brussels 1818).

M. Stuart, Jaarboeken van het Koningrijk der Nederlanden (Amsterdam 1814-1822).

L.C. Sturm, Durch ein grossen Theil von Teutschland und den Niederlanden biss nach Pariss gemachete architectonische Reise-Anmerckungen, zu der Vollständigen Boldmannischen Bau-Kunst VIten Theil als ein Anhang gethan (Augsburg 1719).

E. Van Meteren, Historia, unnd [sic] Abcontrafeytungh, fürnemlich der Niderlendischer geschichten, und Kriegsz hendelen, mit höchstem fleisz beschrieben (Köln 1593). 